\title{
Differential long-term effects of climate change and management on stocks and distribution of soil organic carbon in productive grasslands
}

\author{
A. M. G. De Bruijn ${ }^{1,2}$, P. Calanca ${ }^{1}$, C. Ammann ${ }^{1}$, and J. Fuhrer ${ }^{1}$ \\ ${ }^{1}$ Agroscope ART, Federal Research Station, Air pollution/Climate Group, Reckenholzstrasse 191, 8046 Zürich, Switzerland \\ ${ }^{2}$ Department of Forestry and Natural Resources, Purdue University, West Lafayette, IN 47907-2061, USA \\ Correspondence to: A. M. G. de Bruijn (adebruij@purdue.edu)
}

Received: 14 October 2011 - Published in Biogeosciences Discuss.: 24 January 2012

Revised: 16 April 2012 - Accepted: 25 April 2012 - Published: 7 June 2012

\begin{abstract}
We studied the impact of climate change on the dynamics of soil organic carbon (SOC) stocks in productive grassland systems undergoing two types of management, an intensive type with frequent harvests and fertilizer applications and an extensive system without fertilization and fewer harvests. Simulations were conducted with a dedicated newly developed model, the Oensingen Grassland Model. It was calibrated using measurements taken in a recently established permanent sward in Central Switzerland, and run to simulate SOC dynamics over 2001-2100 under various climate change scenarios assuming different elements of IPCC A2 emission scenarios. We found that: (1) management intensity dominates SOC until approximately 20 years after grassland establishment. Differences in SOC between climate scenarios become significant after 20 years and climate effects dominate SOC dynamics from approximately 50 years after establishment. (2) Carbon supplied through manure contributes about $60 \%$ to measured organic $\mathrm{C}$ increase in fertilized grassland. (3) Soil $\mathrm{C}$ accumulates particularly in the top $10 \mathrm{~cm}$ of the soil until 5 years after establishment. In the long-term, $\mathrm{C}$ accumulation takes place in the top $15 \mathrm{~cm}$ of the soil profile, while $\mathrm{C}$ content decreases below this depth. The transitional depth between gains and losses of $\mathrm{C}$ mainly depends on the vertical distribution of root senescence and root biomass. We discuss the importance of previous land use on carbon sequestration potentials that are much lower at the Oensingen site under ley-arable rotation with much higher SOC stocks than most soils under arable crops. We further discuss the importance of biomass senescence rates, because $\mathrm{C}$ balance estimations indicate that these may differ considerably between the two management systems.
\end{abstract}

\section{Introduction}

Grasslands tend to store more carbon (C) than arable lands, most $\mathrm{C}$ in the soil being organic carbon (SOC). For this reason, previous studies have focused on land use conversion as a measure to mitigate climate change (Schimel, 1995; IPCC, 2000). Some published estimates based on measured changes in SOC $(\triangle \mathrm{SOC})$ in new grasslands are shown in Table 1 . Discussion has evolved, however, on the importance of management in the efficacy of converting arable land to grasslands in order to sequester C.

Dynamics of SOC tend to be mainly driven by litter input and soil respiration, but additional import of manurederived $\mathrm{C}$ has also been shown to increment SOC substantially (Leifeld and Fuhrer, 2010; van Wesemael et al., 2010). Ammann et al. (2007) found that $\triangle \mathrm{SOC}$ is negative in a newly established grassland when it is not fertilized. Effects of climate changes on the effectivity of grassland establishment as a mitigation policy are uncertain (IPCC, 2000; Kätterer et al., 1998; De Bruijn and Butterbach-Bahl, 2010). Some climatic drivers (air temperature and precipitation) affect both $\mathrm{C}$ input by vegetation growth and $\mathrm{C}$ emission by decomposition, while others (radiation, atmospheric $\mathrm{CO}_{2}$ concentrations) affect growth alone. There are indications that SOC in deeper soil has received insufficient attention. Estimates of total SOC, for example by IPCC (2000) or Poeplau et al. (2011), are typically based on statistical upscaling of field measurements. Field sampling, however, tends to focus on the upper soil $(\sim 30 \mathrm{~cm})$ whereas $70 \%$ of soil $\mathrm{C}$ is typically located below $20 \mathrm{~cm}$ depth (Poeplau et al., 2011). 
Table 1. Literature estimates of $\triangle \mathrm{SOC}$ with land use conversions from arable to pasture or management intensification in terms of manure applications and ploughing frequency.

\begin{tabular}{|c|c|c|c|c|c|}
\hline & Author & $\triangle \mathrm{SOC}$ & Period & Soil depth reviewed & Remark \\
\hline \multirow[t]{7}{*}{$\begin{array}{l}\text { Arable soil } \\
\text { to pasture }\end{array}$} & IPCC (2000) & $100 \%$ & long term & unspecified & $\begin{array}{l}\text { Static estimates of stable } \mathrm{C} \text { in different land } \\
\text { use types: } 8 \mathrm{~kg} \mathrm{C} \mathrm{m}^{-2} \\
\text { in arable soil, } 23 \mathrm{~kg} \mathrm{C} \mathrm{m}-2 \text { in grassland }\end{array}$ \\
\hline & \multirow[t]{2}{*}{ Poeplau et al. (2011) } & $+39.8 \pm 11 \%$ & $20 \mathrm{yr}$ & sample mean: $30 \pm 6 \mathrm{~cm}$ & Based on 24 studies/89 data points \\
\hline & & $+128 \pm 23 \%$ & $100 \mathrm{yr}$ & sample mean: $30 \pm 6 \mathrm{~cm}$ & Based on 24 studies/89 data points \\
\hline & Lal (2007) & $+400-600 \mathrm{~kg} \mathrm{ha}^{-1}$ & $1 \mathrm{yr}$ & unspecified & \\
\hline & Conant et al. (2001) & $1010 \mathrm{~kg} \mathrm{ha}^{-1}$ & $1 \mathrm{yr}$ & sample mean: $30.5 \mathrm{~cm}$ & $\begin{array}{l}\text { Conversion: cultivation to pasture } \\
\text { ( } 23 \text { data points) }\end{array}$ \\
\hline & \multirow[t]{2}{*}{ Ammann et al. (2007) } & $1470 \pm 1300 \mathrm{~kg} \mathrm{ha}^{-1}$ & $1 \mathrm{yr}$ & $\begin{array}{l}\text { sample max: } \\
40 \mathrm{~cm}\end{array}$ & $\begin{array}{l}\text { Intensive management (INT) } \\
\text { as in this manuscript }\end{array}$ \\
\hline & & $\begin{array}{l}-570(+1300 /-1100) \\
\mathrm{kg} \mathrm{ha}^{-1}\end{array}$ & $1 \mathrm{yr}$ & $\begin{array}{l}\text { sample max: } \\
40 \mathrm{~cm}\end{array}$ & $\begin{array}{l}\text { Extensive management } \\
(\text { EXT) as in this manuscript }\end{array}$ \\
\hline \multirow[t]{2}{*}{ Intensification } & Lal (2007) & $100-200 \mathrm{~kg} \mathrm{ha}^{-1}$ & $1 \mathrm{yr}$ & unspecified & West and Post (2002) in Lal (2007) \\
\hline & Conant et al. (2001) & $300 \mathrm{~kg} \mathrm{ha}^{-2}$ & $1 \mathrm{yr}$ & sample mean: $30.5 \mathrm{~cm}$ & Fertilization (42 datapoints) \\
\hline
\end{tabular}

The goal of our study was to examine how $\triangle \mathrm{SOC}$ depends on climate and management at different soil depths and time scales in a newly established grassland. Biogeochemical models have proven useful to improve knowledge about long-term $\triangle$ SOC (DNDC: Li et al., 1992; RothC: Jenkinson et al., 1991; PaSim: Riedo et al., 1998; CENTURY: Parton et al., 1987; Kulshreshtha and Sobool, 2006). For our study, we developed a new semi-empirical computer simulation model that describes interactions between plant and soil $\mathrm{C}: \mathrm{N}$ processes to study $\triangle \mathrm{SOC}$ after conversion of cropland to grassland at a site in Central Switzerland (Oensingen). The Oensingen Grassland Model (OGM) was calibrated using measurements taken in 2001-2009 at the ongoing longterm experiment at Oensingen that started in 2000. These data are particularly valuable because two parallel grassland plots were established on the same arable field, but developed under different management (Ammann et al., 2007, 2009). Model runs were used to simulate long term (100 year) $\triangle$ SOC under variable management and climatic conditions.

\section{Materials and methods}

\subsection{Field observation dataset}

Measurements were taken between 2002 and 2010 (Table 2). The FLUXNET grassland site Oensingen is located in central Switzerland $\left(7^{\circ} 44^{\prime} \mathrm{E}, 47^{\circ} 17^{\prime} \mathrm{N}, 450 \mathrm{~m}\right.$ a.s.l.). It has a mixed maritime/continental climate with high annual rainfall $(1100 \mathrm{~mm})$. Mean annual air temperature is $9.5^{\circ} \mathrm{C}$. The soil is classified as Eutri-Stagnic Cambisol (FAO, ISRIC and ISSS, 1998) developed on clayey alluvial deposits. Clay content is between $42 \%$ and $44 \%$, total pore volume is $50-55 \%$ and fine pore volume is $32 \%$. Until the year 2000, the field has been under ley-arable rotation with a typical 8-year cycle. Fertilization with $\mathrm{N}$ depended on crop type and followed the
Swiss standard fertilization practice $\left(110 \mathrm{~kg} \mathrm{Nha}^{-1} \mathrm{yr}^{-1}\right.$ on average). The field was last ploughed in November 2000 after which it was divided into two equal sized ( $0.77 \mathrm{ha}$ ) rectangular plots (Ammann et al., 2007) and converted to permanent grassland.

The two grassland management systems were named intensive management (INT) and extensive management (EXT) in previous publications that discuss the Oensingen experiments (Ammann et al., 2007, 2009; Leifeld et al., 2011). The plots were sown in May 2001: INT with 7 species of grass and clover, EXT with 30 species of grass, clover and herbs (Ammann et al., 2009). Grass clippings are usually hayed or used for silage. INT is fertilized with solid ammonium nitrate (approximately $120 \mathrm{~kg} \mathrm{ha}^{-1}$ per treatment) or liquid cattle manure (approximately $32 \mathrm{~m}^{3} \mathrm{ha}^{-1}$ per treatment) at the beginning of each growing cycle. EXT remains unfertilized. The number of harvests depends on the observed productivity of the field and follows the normal agricultural practice in the region. EXT typically remains uncut until June and is typically cut 3 times per year whereas INT is typically cut 4 times per year. Ammann et al. (2009) found that EXT had a negative $\mathrm{N}$ balance during 2001-2006.

\subsection{Model description}

In general, we were aiming to maintain the advantages of a process-based model (e.g. the ability to improve qualitative understanding rather than just to quantify relevant processes), while using few parameters and mathematical descriptions that are basic. Such setup was thought to optimize model robustness and to minimize model stiffness or overparameterization, issues that have been identified as drawbacks for some commonly used models (Kesik et al., 2005; De Bruijn and Butterbach-Bahl, 2010).

The OGM model simplifies by lumping molecular varieties in which $\mathrm{C}$ and $\mathrm{N}$ elements occur in the soil and vegetation, it does not explicitly calculate microbial population 
Table 2. Measurements taken in the context of the Oensingen experiments, used in this study (Ammann et al., 2007, 2009).

\begin{tabular}{lll}
\hline Measurement & Time span & Management \\
\hline Air temperature & $1981-2010$ & INT+EXT \\
Precipitation & $1981-2010$ & INT+EXT \\
Soil temperature & $2002-2010$ & INT \\
Soil moisture & $2002-2010$ & INT \\
Root biomass & 2004 & INT+EXT \\
Leaf area index (LAI) & $2003-2010$ & INT+EXT \\
Soil C/N ratio, bulk density, porosity, organic C & 2002 & INT+EXT \\
Soil-atmosphere $\mathrm{CO}_{2}$ exchange & $2002-2010$ & INT+EXT \\
Manure application & $2002-2010$ & INT \\
Cut biomass & $2002-2009$ & INT+EXT \\
Harvested biomass & $2002-2009$ & INT+EXT \\
\hline
\end{tabular}

dynamics, uses few decomposition pools and a limited number of input parameters. When compared to some of the more frequently used biogeochemical models, it resembles RothC and CENTURY rather than DNDC or PaSim. In contrast with RothC and CENTURY however, it maintains daily rather than monthly or annual integration steps. The development of a new model, moreover, allowed us to experiment with some alternative approaches.

OGM simulates a soil-plant system in one spatial dimension, with modules for temperature, moisture and $\mathrm{C}$ and $\mathrm{N}$ dynamics (Fig. 1). It uses three driving climatic variables (temperature, radiation, and precipitation), atmospheric $\mathrm{CO}_{2}$ concentration, 4 input parameters per soil layer (bulk density, porosity, $\mathrm{C}$ content and $\mathrm{C}: \mathrm{N}$ ratio), 19 parameters that are specific for a vegetation type (e.g. water use efficiency, root/shoot turnover rate, specific leaf area), and 24 parameters that are site or soil type specific (e.g. potential decomposition rates, optimum decomposition temperature, moisture, etc.). The latter, when describing soil properties, are assumed constant with soil depth. The OGM model uses daily averages for temperature and radiation, and daily sums for precipitation. The user can prescribe sub-daily time steps, however, to prevent numerical instabilities. Results presented here were obtained with an hourly time step. The model integrates virtual soil layers, assuming constant conditions in each layer. The user can set the thickness of each layer depending on research interests and the availability of data. For the present simulations, the soil profile was divided into 11 layers $(2 \times 5 \mathrm{~cm}, 9 \times 10 \mathrm{~cm})$ to simulate a total soil depth of $1.0 \mathrm{~m}$. OGM has a Microsoft Windows-specific (Visual C++) user interface which is separated from the model calculations that are ANSII compliant $(\mathrm{C}++)$.

\subsubsection{Temperature and moisture}

The temperature submodel is common to many soil biogeochemistry models; we will not describe it in detail here. A simple cascade approach was used to model soil moisture. The main processes that drive soil moisture are soil water movement and uptake of soil moisture by the vegetation. Water movement depends on water potentials that change with soil moisture in adjacent layers. Water uptake depends on soil moisture and root density. Further details of the water and temperature submodel can be found in Müller (2000).

\subsubsection{Carbon and nitrogen balance}

Plants can assimilate atmospheric $\mathrm{CO}_{2}$ and fix $\mathrm{N}_{2}$ through root symbiosis with rhizobia (Biological Nitrogen Fixation, $\mathrm{BNF}$ ). The model treats organic manure-related additions of $\mathrm{C}$ and $\mathrm{N}$ (organic manure is always cattle slurry in INT) similar to inputs of plant residues since it increases the decomposition pools according to concentrations of $\mathrm{C}, \mathrm{N}$ and a fraction of manure that is labile.

While acknowledging that there is ongoing discussion about the biophysical interpretation of modeled decomposition pools, OGM conforms with models such as RothC, DNDC, COUP, or, CENTURY, by using conceptual rather than measurable decomposition pools, mainly in order to reduce the number of pools and to simplify model parameterization (De Bruijn and Butterbach-Bahl, 2010; Parton et al., 1987; Li et al., 1992; Xu et al., 2011). OGM uses four decomposition pools, two for $\mathrm{C}$ and two for $\mathrm{N}$ distinguished according to decomposability $\left(\mathrm{C}_{\text {labile }} \mathrm{N}_{\text {labile }}\right.$, $\left.\mathrm{C}_{\text {recalcitrant }}, \mathrm{N}_{\text {recalcitrant }}\right)$. Inorganic manure-bound $\mathrm{N}$ increases a separate pool of dissolved organic (DON) and inorganic (DIN) $\mathrm{N}$ ( Ndiss $_{\mathrm{sl}}$ : DON+DIN in soil layer sl). Extraction of $\mathrm{C}$ and $\mathrm{N}$ occurs with harvests, net emission of $\mathrm{CO}_{2}$ and nitrogenous gases, or through leaching of Ndiss $\mathrm{s}_{\mathrm{s}}$. Leaching of DOC has not been investigated at the Oensingen field site, but Zeeman (2008) found that $\mathrm{C}$ leaching in a similar site in Switzerland was very small $\left(0.05 \mathrm{tC} \mathrm{ha}^{-1} \mathrm{yr}^{-1}\right)$.

OGM calculates gaseous $\mathrm{N}$ emissions $\left(\mathrm{N}_{\text {emissions }}\right)$ or $\mathrm{N}$ leachates $\left(\mathrm{N}_{\text {leaching }}\right)$, but it does not specify species of $\mathrm{N}$ gases $\left(\mathrm{NO}_{\mathrm{y}}, \mathrm{NH}_{3}\right)$ or leachates $\left(\mathrm{DON}, \mathrm{NO}_{3}^{-}, \mathrm{NH}_{4}^{+}\right)$. In consequence, OGM cannot be calibrated for accuracy of $\mathrm{N}$ emission rates, even though emissions are constrained by the decomposition rates and $\mathrm{C}: \mathrm{N}$ ratio of the decomposition pools 

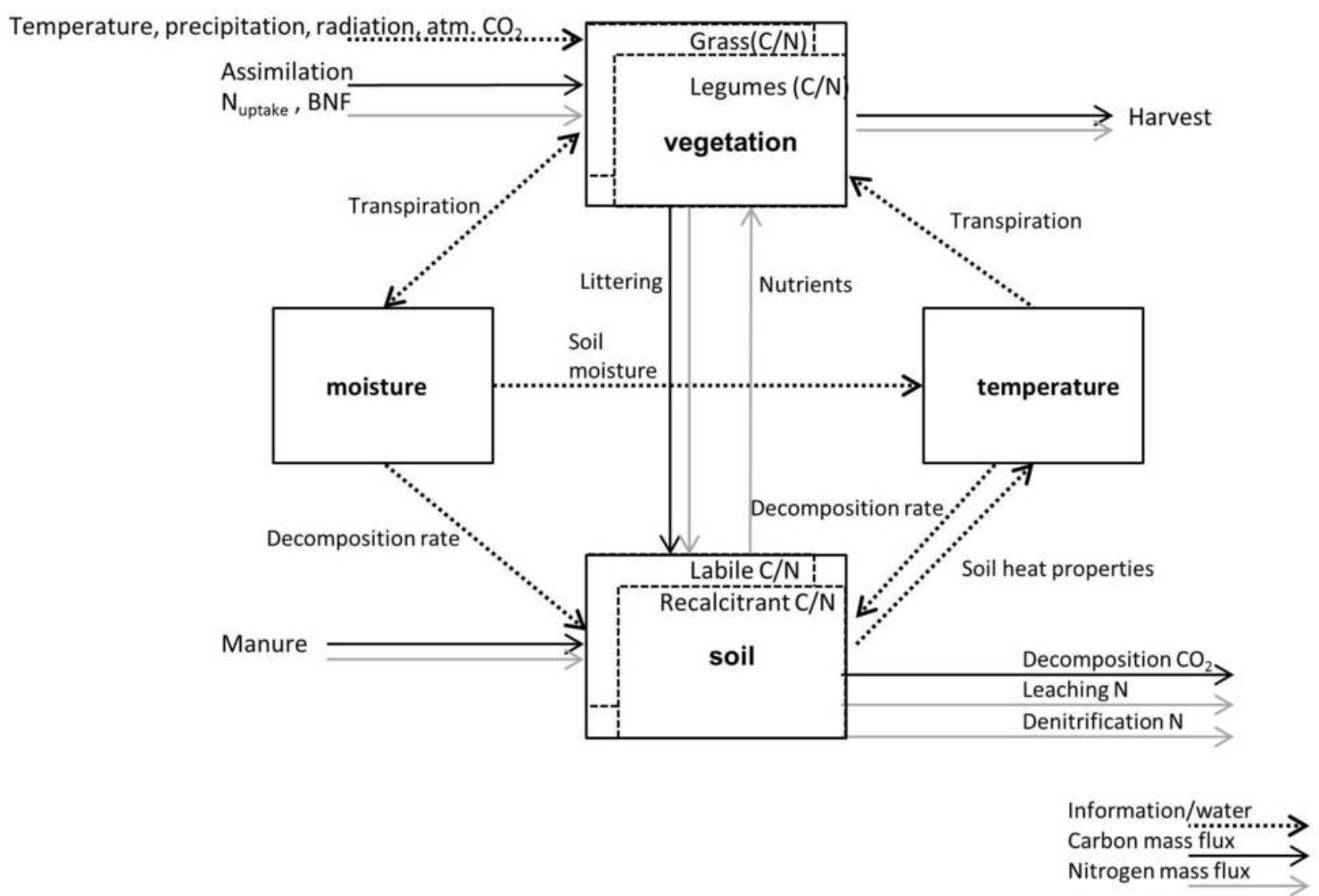

Fig. 1. Overview of the Oensingen Grassland Model. The 4 solid-lined boxes are the main modules. The vegetation module can contain multiple plant functional types (here: grass and legumes in dotted boxes). The soil contains two decomposition pools, expressed in terms of $\mathrm{C}$ and $\mathrm{N}$ (dotted boxes). Arrows denote relationships between the modules. They can refer either to mass or information fluxes.

in the model. The OGM model uses plant functional types (i.e. categories of species with a similar growth strategy, phenotypical characterization, nutrient/moisture uptake capacities, etc.) to deal with interspecies variability. Biochemical behavior of a functional type is described with unified equations that can be parameterized differently. For the present simulations two plant functional types were used: legumes $(\mathrm{v}=0)$ and grasses $(\mathrm{v}=1)$. In the following, subscripts $\mathrm{v}, \mathrm{d}$, and sl are used to refer to individual vegetation types $\{\mathrm{v}=0,1$ for grass and legumes $\}$, decomposition pools $\{\mathrm{d}=0,1$ for labile and recalcitrant $\}$, and soil layers $\{\mathrm{sl}=0$,slMax for increasing depth $\}$.

Net ecosystem exchange (NEE) is the sum of $\mathrm{CO}_{2}$ assimilation and respiration:

$\mathrm{NEE}=\sum_{\mathrm{v}=0}^{1}\left(\frac{\delta \mathrm{C}}{\delta t}\right)_{\mathrm{assim}, \mathrm{v}}-\sum_{\mathrm{d}=0}^{1}\left(\frac{\delta \mathrm{C}}{\delta t}\right)_{\text {decomposition, } \mathrm{d}}$

where $\left(\frac{\delta \mathrm{C}}{\delta t}\right)_{\text {assim,v }}$ is net assimilation by plant type $\mathrm{v}$, and $\left(\frac{\delta \mathrm{C}}{\delta t}\right)_{\text {decomposition,d }}$ is decomposition-related loss of $\mathrm{C}$ from decomposition pool d. Net biomass productivity (NBP) is the sum of $\mathrm{C}$ input and losses including management induced changes:

$\mathrm{NBP}=\mathrm{NEE}+\left(\frac{\delta \mathrm{C}}{\delta t}\right)_{\text {manure }}-\sum_{v=0}^{1}\left(\frac{\delta \mathrm{C}}{\delta t}\right)_{\text {harvest }, \mathrm{v}}$

where $\left(\frac{\delta \mathrm{C}}{\delta t}\right)_{\text {harvest, } \mathrm{v}}$ is biomass that is removed with harvests and $\left(\frac{\delta \mathrm{C}}{\delta t}\right)_{\text {manure }}$ is manure-bound $\mathrm{C}$. All variables are expressed in $\mathrm{g} \mathrm{C} \mathrm{m}^{-2}$. The $\mathrm{N}$ balance is calculated according to:

$\left.\left(\frac{\delta \mathrm{N}}{\delta t}\right)_{\text {system }}=\sum_{\mathrm{v}=0}^{1}\left(\left(\frac{\delta \mathrm{N}}{\delta t}\right)_{\mathrm{BNF}, \mathrm{v}}-\left(\frac{\delta \mathrm{N}}{\delta t}\right)_{\text {harvest, } \mathrm{v}}\right)\right)$

$+\left(\frac{\delta \mathrm{N}}{\delta t}\right)_{\text {manure }}-\left(\frac{\delta \mathrm{N}}{\delta t}\right)_{\text {emission }}-\left(\frac{\delta \mathrm{N}}{\delta t}\right)_{\text {leaching }}$

where $\left(\frac{\delta \mathrm{N}}{\delta t}\right)_{\mathrm{BNF}, \mathrm{v}}$ is $\mathrm{N}$ fixation by $\mathrm{v},\left(\frac{\delta \mathrm{N}}{\delta t}\right)_{\text {harvest, } \mathrm{v}}$ is $\mathrm{N}$ that is removed with harvest. $\left(\frac{\delta \mathrm{N}}{\delta t}\right)_{\text {manure }}$ is manure-bound $\mathrm{N}$, $\left(\frac{\delta \mathrm{N}}{\delta t}\right)_{\text {emission }}$ is $\mathrm{N}$ gaseous emission. $\left(\frac{\delta \mathrm{N}}{\delta t}\right)_{\text {leaching }}$ is $\mathrm{N}$ leaching. All variables are expressed in $\mathrm{g} \mathrm{N} \mathrm{m}^{-2}$.

\subsubsection{Vegetation}

Steduto et al. (2009) developed the AquaCrop model which assumes that plant growth correlates well with crop transpiration under nutrient-saturated conditions. In agreement with 
AquaCrop, OGM uses crop transpiration as the main driver of assimilation:

$\left(\frac{\delta \mathrm{C}}{\delta t}\right)_{\text {assim,v }}=\mathrm{Ns}_{\mathrm{v}} \times \mathrm{WUE}_{\mathrm{v}} \times\left(1.0+P_{\mathrm{CO}_{2}, \mathrm{v}}\right) \times \operatorname{Tr}_{\mathrm{v}}$

where $\mathrm{WUE}_{\mathrm{v}}$ is the potential water use efficiency of $\mathrm{v}$ under current levels of atmospheric $\mathrm{CO}_{2}\left(\mathrm{~g} \mathrm{C} \mathrm{mm}^{-1} \mathrm{H}_{2} \mathrm{O}\right), \mathrm{Ns}_{\mathrm{v}}$ is a growth rate reduction factor that depends on the concentration of $\mathrm{N}$ in leaves and $\mathrm{Tr}_{\mathrm{v}}$ is transpiration by $\mathrm{v} . \mathrm{P}_{\mathrm{CO}_{2}}$ is the relative increase of WUE (\%) with increasing concentrations of atmospheric $\mathrm{CO}_{2}$ :

$P_{\mathrm{CO}-2, \mathrm{v}}=\frac{D_{\mathrm{CO}-2, \mathrm{v}}}{100 \%} \times\left(\frac{\rho_{\mathrm{CO}-2}-370}{370}\right)$

where $\rho_{\mathrm{CO}-2}$ is the concentration of atmospheric $\mathrm{CO}_{2}$ in $\mathrm{ppm}, \mathrm{D}_{\mathrm{CO}-2, \mathrm{v}}$ is the rate increase of photosynthesis in $\mathrm{v}$ if atmospheric concentration of $\mathrm{CO}_{2}$ doubles compared to current $\rho_{\mathrm{CO}-2}=370 \mathrm{ppm}$. Published estimates of $\mathrm{D}_{\mathrm{CO}-2, \mathrm{v}}$ for species in INT and EXT range from $20-40 \%$ and estimates of individual species typically differ as much as those between species (Aeschlimann et al., 2005; Ainsworth et al., 2003; Casella and Soussana, 1997; Ryle et al., 1992). In the present model applications, we used $\mathrm{D}_{\mathrm{CO}_{2}}=33 \%$ for both grasses and legumes (C3 plants) based on an extensive literature review by Wand et al. (1999).

The $\mathrm{N}$ stress factor $\mathrm{Ns}_{\mathrm{v}}$ is calculated from foliage $\mathrm{N}$ according to

$\mathrm{Ns}_{\mathrm{v}}=\left(\frac{\mathrm{C} 2 \mathrm{Nf}_{\mathrm{v}}}{\mathrm{C} 2 \mathrm{~N}} \text { OPT,v }\right)^{\lambda \mathrm{Ns}_{\mathrm{v}}}$

where $\mathrm{C} 2 \mathrm{Nf}_{\mathrm{v}}$ and $\mathrm{C} 2 \mathrm{~N}_{\mathrm{OPT}, \mathrm{v}}$ are current and optimal C:N ratio in foliage of $\mathrm{v}, \lambda \mathrm{Ns}_{\mathrm{v}}$ is a tuning parameter applied to $\mathrm{v}$. Transpiration $\operatorname{Tr}_{v}$ in Eq. (4) is calculated from potential evapotranspiration $\left(\mathrm{ET}_{0}\right)$, which is estimated from air temperature and radiation according to Priestley and Taylor (1972). Evaporation (E) and transpiration (T) are difficult to estimate in isolation. Some estimates given for example by Ham et al. (1990) suggest that $T>>E$ in almost all stages of a developing vegetation, which indicates that $\mathrm{E}$ from a developed canopy is very small. However, $\mathrm{T}$ equals zero by definition when $\mathrm{LAI}=0$, and a sharp decrease of $\mathrm{E} / \mathrm{ET}_{0}$ from 1.0 to 0.0 with increasing LAI is therefore necessary. Due to a lack of measurements of $\mathrm{T}$, we are using the total leaf area index $\operatorname{LAI}_{\text {tot }}\left(=\Sigma \mathrm{LAI}_{\mathrm{v}}\right)$ and we assume that $\mathrm{E}$ is negligible when $\mathrm{LAI}_{\text {tot }}>1.0 \mathrm{~m}^{2} \mathrm{~m}^{-2}$ (thus $\mathrm{PT}_{\text {tot }}=\mathrm{ET}_{0}$ ) and that $\mathrm{PT}_{\text {tot }}$ $=\mathrm{LAI}_{\text {tot }} \times \mathrm{ET}_{0}$ when $\mathrm{LAI}_{\text {tot }}<1.0$. Some estimates indicate that this approximation may underestimate $\mathrm{E}$ with maximum $10 \%$ when LAI $\sim 1.0$. In view of the magnitude of uncertainties we are dealing with in modeling biogeochemistry of a field site, we feel that this is acceptable (Ham et al., 1990; Saugier and Katerji, 1991; Merta et al., 2006).

$\mathrm{PT}_{\mathrm{V}}$ is derived from $\mathrm{PT}_{\text {tot }}$ using the dominance in foliage cover, $\operatorname{dom}_{\mathrm{v}}=\mathrm{LAI}_{\mathrm{v}} / \mathrm{LAI}_{\text {tot }}$, assuming that the capacity of a vegetation type to dominate water uptake of an ecosystem with more than one type of vegetation $\left(\mathrm{PT}_{\mathrm{v}} / \mathrm{PT}_{\text {tot }}\right)$ correlates linearly with $\operatorname{dom}_{\mathrm{v}}\left(\mathrm{PT}_{\mathrm{v}}=\mathrm{dom}_{\mathrm{v}} \mathrm{PT}_{\text {tot }}\right)$. The actual transpiration of $\mathrm{v}\left(\mathrm{Tr}_{\mathrm{v}}\right)$ is estimated from $\mathrm{PT}_{\mathrm{v}}$ according to root biomass and moisture availability in individual soil layers:

$\operatorname{Tr}_{\mathrm{v}}=\sum_{\mathrm{sl}=0}^{\text {slMax }}\left(\mathrm{fr}_{\mathrm{sl}, \mathrm{v}} \times\left(\frac{\theta_{\mathrm{sl}}-\theta_{\text {wilt, } \mathrm{v}}}{\theta_{\text {poro }}-\theta_{\text {wilt, } \mathrm{v}}}\right)^{\lambda \mathrm{s}_{\mathrm{v}}} \times \mathrm{PT}_{\mathrm{v}}\right)$

where $\mathrm{fr}_{\mathrm{sl}, \mathrm{v}}$ is the fraction of root biomass of $\mathrm{v}$ in soil layer sl (see also Eq. 12), slMax is the number of soil layers and $\theta_{\mathrm{sl}}$ is the water content in $\mathrm{sl}$ (VOL \%), $\theta_{\text {wilt,v }}$ is soil moisture content at the level where v starts to wilt (VOL \%), $\theta_{\text {poro }}$ is water content at field capacity (VOL \%) and $\lambda \mathrm{s}_{\mathrm{v}}$ is a tuning parameter.

$\mathrm{N}$ uptake by plant roots is calculated according to:

$\left(\frac{\delta \mathrm{N}}{\delta t}\right)_{\text {uptake }, \mathrm{v}}=\sum_{\mathrm{sl}=0}^{\mathrm{slMax}} \mathrm{Nup}_{\mathrm{v}} \times \mathrm{Ndiss}_{\mathrm{sl}} \times \mathrm{fr}_{\mathrm{sl}, \mathrm{v}} \times \mathrm{Br}_{\mathrm{v}}$

where $\mathrm{Nup}_{\mathrm{v}}$ is uptake capacity by roots of $\mathrm{v}\left(\mathrm{g}_{\mathrm{N}} / \mathrm{g}_{\mathrm{DW}}(\right.$ root $\left.)\right)$, $\mathrm{Br}_{\mathrm{v}}=$ root biomass of $\mathrm{v}\left(\mathrm{g}_{\mathrm{DW} \mathrm{m}}{ }^{-2}\right)$. The OGM model assumes that BNF correlates linearly with root volume:

$$
\left(\frac{\delta \mathrm{N}}{\delta t}\right)_{\mathrm{BNF}, \mathrm{v}} \sum_{\mathrm{sl}=0}^{\mathrm{slMax}}\left(\mathrm{BNFC}_{\mathrm{v}} \times \mathrm{fr}_{\mathrm{sl}, \mathrm{v}} \times \mathrm{Br}_{\mathrm{v}}\right)
$$

where $\mathrm{BNFC}_{\mathrm{v}}$ is the rate of $\mathrm{N}_{2}$ fixation by roots of $\mathrm{v}\left(\mathrm{g}_{\mathrm{N}}\right.$ $\mathrm{g}_{\mathrm{DW}}(\text { root })^{-1}$ ), with $\mathrm{BNFC}_{\mathrm{v}}=0.0$ when simulating species that are incapable of fixing atmospheric $\mathrm{N}_{2}$.

Two pools are used to describe vegetation development (Bs: shoot biomass and Br: root biomass; both in $\mathrm{g} \mathrm{DW} \mathrm{m}^{-2}$ ). The density of $\mathrm{C}$ in a component is a fixed parameter but the $\mathrm{C}: \mathrm{N}$ ratio fluctuates. We are assuming that plants improve access to $\mathrm{N}$ by investing in roots when the $\mathrm{C}: \mathrm{N}$ ratio in foliage increases, or vice versa, plants increase foliage biomass to improve assimilation of $\mathrm{C}$ when the $\mathrm{C}: \mathrm{N}$ ratio drops (Thornley and Johnson, 1990):

$\mathrm{fCa}_{\mathrm{v}}=\lambda \mathrm{Ca}_{\mathrm{v}} \times\left(\frac{\mathrm{C} 2 \mathrm{~N}_{\mathrm{OPT}, \mathrm{v}}}{\mathrm{C} 2 \mathrm{Ns}}\right)$

where $\mathrm{fCa}_{\mathrm{v}}$ is the fraction of assimilated $\mathrm{C}$ that is allocated aboveground, $\mathrm{C} 2 \mathrm{~N}_{\mathrm{opt}, \mathrm{v}} / \mathrm{C} 2 \mathrm{Ns}$ is shoot $\mathrm{N}$ status (capped to exclude values larger than 1.0) and $\lambda \mathrm{Ca}_{\mathrm{v}}$ is a tuning parameter. We further assume that foliage growth and $\mathrm{N}$ allocation does not depend on root $\mathrm{C}: \mathrm{N}$ ratio, that aboveground allocation of $\mathrm{N}\left(\mathrm{fNa}_{\mathrm{v}}\right.$ : the fraction of $\mathrm{N}$ that is allocated to aboveground parts) decreases as $\mathrm{C} 2 \mathrm{Ns}$ drops below $\mathrm{C}_{2} \mathrm{~N}_{\mathrm{opt}, \mathrm{v}}$, and that roots are used to store excess $\mathrm{N}$. For $\mathrm{fNa}_{\mathrm{v}}$ we used:

$\mathrm{fNa}_{\mathrm{v}}=1.0-\lambda \mathrm{Cb}_{\mathrm{v}} \times\left(\frac{\mathrm{C} 2 \mathrm{~N}_{\mathrm{OPT}, \mathrm{v}}}{\mathrm{C} 2 \mathrm{Ns}}\right)$

Root biomass distribution is commonly modeled assuming an exponential decrease of root biomass with depth (Gerwitz and Page, 1974). However, data for root biomass measured 
at Oensingen suggest that this assumption tends to underestimate root biomass in the top soil layer. Alternatively, we used:

$$
\mathrm{Br}_{\mathrm{v}, \mathrm{sl}}=\mathrm{Br}_{\mathrm{v}} \times \frac{\left(\mathrm{D} \max _{\mathrm{v}} / \mathrm{D}_{\mathrm{sl}}\right)^{\lambda \mathrm{Br}}}{\sum_{\mathrm{sl}=0}^{\mathrm{slMax}}\left(\mathrm{Dmax}_{\mathrm{v}} / \mathrm{D}_{\mathrm{sl}}\right)^{\lambda \mathrm{Br}}}
$$

where $\mathrm{Br}_{\mathrm{v}, \mathrm{sl}}$ is root biomass of $\mathrm{v}$ in $\mathrm{sl}, \mathrm{Br}_{\mathrm{v}}$ is the total root biomass of $\mathrm{v}\left(\mathrm{g}_{\mathrm{DW}} \mathrm{m}^{-2}\right), \mathrm{Dmax}_{\mathrm{v}}$ is rooting depth of vegetation type $\mathrm{v}(\mathrm{m}), \mathrm{D}_{\mathrm{sl}}$ is the depth of soil layer sl (m), and parameter $\lambda \mathrm{Br}$ is a shape parameter.

Foliage turnover $\left(\frac{\delta \mathrm{Bs}}{\delta t}\right)_{\text {turnover,v }}$ depends on an intrinsic turnover rate which expresses the effect of ageing, and of water stress:

$\left(\frac{\delta \mathrm{Bs}}{\delta t}\right)_{\text {turnover, } \mathrm{v}}=\left(\mathrm{TOf}_{\mathrm{v}}+\lambda \mathrm{sO}_{\mathrm{v}} \times \frac{\mathrm{TR}_{\mathrm{v}}}{\mathrm{PT}_{\mathrm{v}}}\right) \times \mathrm{Bs}_{\mathrm{v}}$

where $\mathrm{TOf}_{\mathrm{v}}$ is reference foliage turnover rate and $\lambda \mathrm{sTO}$ is a shape parameter that increases foliage decay with water stress $\left(\mathrm{m}^{-1}\right)$. Root biomass turnover $\left(\frac{\delta \mathrm{Br}}{\delta t}\right)_{\text {turnover, } \mathrm{v}}$ is a constant fraction $\left(\mathrm{TOr}_{\mathrm{rv}}\right.$ in $\mathrm{kg}_{\mathrm{DW}} \mathrm{kg}_{\mathrm{DW}}^{-1}$ ) of root biomass:

$\left(\frac{\delta \mathrm{Br}}{\delta t}\right)_{\text {turnover, }, \mathrm{sl}}=\mathrm{TOr}_{\mathrm{v}} \times \mathrm{Br}_{\mathrm{v}, \mathrm{sl}}$

The model assumes that harvest index (HI: extracted biomass/cut biomass) is constant regardless of harvesting method:

$\left(\frac{\delta \mathrm{Bs}}{\delta t}\right)_{\text {harvest }, \mathrm{v}}=\mathrm{HI} \times\left(\frac{\delta \mathrm{Bs}}{\delta t}\right)_{\text {cut }, \mathrm{v}}$

The volume of cut biomass is estimated by subtracting the aboveground biomass that remains after a cut $\left(\mathrm{Bi}_{\mathrm{V}}\right.$ is derived from a vegetation specific parameter $\mathrm{LAI}_{\text {init,v }}$ that is the LAI of $\mathrm{v}$ immediately after emergence) from biomass volume at the time of the cut $\left(\mathrm{Bs}_{\mathrm{V}}\right)$ :

$\left(\frac{\delta \mathrm{Bs}}{\delta t}\right)_{\mathrm{cut}, \mathrm{v}}=\left(1.0-\mathrm{Bi}_{\mathrm{v}}\right) \times \mathrm{Bs}_{\mathrm{v}}$

The remaining biomass (cut but not removed) is added to the soil together with other residues:

$\left(\frac{\delta \mathrm{C}}{\delta t}\right)_{\text {harv_litter, } \mathrm{v}}=\left(\frac{\delta \mathrm{Bs}}{\delta t}\right)_{\text {cut }, \mathrm{v}}-\left(\frac{\delta \mathrm{Bs}}{\delta t}\right)_{\text {harvest, } \mathrm{v}}$

where $\left(\frac{\delta \mathbf{C}}{\delta t}\right)_{\text {harv_litter,v }}$ are biomass residues after a harvest.

The current model structure cannot deal with grazing, which is not part of management systems applied at the Oensingen grasslands. Inclusion of grazing would require additional parameterization of cattle density and activity. We do expect however, that model performance in such setup would be lower due to spatial variability of manure additions which cannot be accounted for in a 1-D model.

\subsubsection{Soil}

Input of plant litter expressed in terms of $\mathrm{C}$ of $\mathrm{v}$ that is transported to $\mathrm{C}_{\mathrm{d}}\left(\mathrm{C}_{0}=\mathrm{C}_{\text {labile }}, \mathrm{C}_{1}=\mathrm{C}_{\text {recalcitrant }}\right)$ is expressed according to:

$$
\begin{aligned}
\left(\frac{\delta \mathrm{C}}{\delta t}\right)_{\text {litter, }, \mathrm{v}} & =\sum_{\mathrm{sl}=0}^{\mathrm{slMax}}\left(\mathrm{fr}_{\mathrm{v}, \mathrm{sl}} \times \mathrm{f}_{\mathrm{d}} \times \rho \mathrm{Cr}_{\mathrm{v}}\left(\frac{\delta \mathrm{Br}_{\mathrm{sl}}}{\delta \mathrm{t}}\right)_{\text {turnover, } \mathrm{v}}\right) \\
& +f_{\mathrm{d}} \times \rho \mathrm{Cs}_{\mathrm{v}}\left(\frac{\delta \mathrm{Bs}}{\delta t}\right)_{\text {turnover, } \mathrm{v}}+\left(\frac{\delta \mathrm{C}}{\delta t}\right)_{\text {harv_litter }, \mathrm{v}}
\end{aligned}
$$

where $\mathrm{fr}_{\mathrm{v}, \mathrm{sl}}$ is the fraction of root biomass of $\mathrm{v}$ in $\mathrm{sl}$ (derived from Eq. 12), $f_{d}$ is the fraction of labile $(d=0)$ or recalcitrant $(\mathrm{d}=1)$ constituents in turnover biomass, $\rho \mathrm{Cr}_{\mathrm{V}}$ and $\rho \mathrm{Cs}_{\mathrm{V}}$ are concentrations of $\mathrm{C}$ in root and shoot biomass $\left(\mathrm{g} \mathrm{Cg}^{-1} \mathrm{DW}\right)$. Additions to the $\mathrm{N}$ pools are expressed similarly, where $\rho \mathrm{Nr}_{\mathrm{V}}$ (calculated dynamically) is applied instead of $\rho \mathrm{Cr}_{\mathrm{V}}, \rho \mathrm{Ns}_{\mathrm{V}}$ instead of $\rho \mathrm{Cs}_{\mathrm{v}}, \delta \mathrm{N} / \delta \mathrm{t}$ instead of $\delta \mathrm{C} / \delta \mathrm{t}$.

The OGM user can specify manure applications as inor-

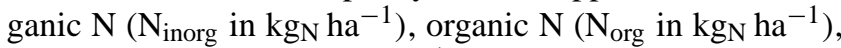
and organic $\mathrm{C}\left(\mathrm{C}_{\mathrm{org}}\right.$ in $\left.\mathrm{kg}_{\mathrm{C}} \mathrm{ha}^{-1}\right)$. Organic manure enters a $\mathrm{C}$ pool according to:

$\left(\frac{\delta \mathrm{C}}{\delta t}\right)_{\text {litter, }, \mathrm{sl}=0}=f m_{\mathrm{d}} \times\left(\frac{\delta \mathrm{C}}{\delta t}\right)_{\text {manure }}$

where $\mathrm{fm}_{\mathrm{d}}$ is the fraction of a component $(\mathrm{d}=0,1$ for labile and recalcitrant) in applied manure. Additions to $\mathrm{N}_{\mathrm{d}}$ are calculated with a similar equation $\left(\mathrm{N}_{\mathrm{d}}\right.$ for $\left.\mathrm{C}_{\mathrm{d}}\right)$. $\mathrm{N}_{\text {inorg }}$ is added to $\mathrm{Ndiss}_{\mathrm{sl}}$ in the top layer $(\mathrm{sl}=0)$ of the soil:

$\left(\frac{\delta \mathrm{Ndiss}}{\delta t}\right)_{\text {litter }, \mathrm{s}=0}=\left(\frac{\delta \mathrm{N}}{\delta t}\right)_{\text {manure }}$

Decomposition of $\mathrm{C}$ from a pool $\mathrm{C}_{\mathrm{d}}$ is calculated according to:

$\left(\frac{\delta \mathrm{C}}{\delta t}\right)_{\mathrm{dec}, \mathrm{d}, \mathrm{sl}}=K_{\mathrm{d}} \times \tau_{\mathrm{sl}} \times m_{\mathrm{sl}} \times C_{\mathrm{d}, \mathrm{sl}}$

where $\mathrm{K}_{\mathrm{d}}$ is the potential decomposition rate of $\mathrm{d}, \tau_{\mathrm{sl}}$ and $m_{\mathrm{sl}}$ are temperature and moisture dependent reduction factors for the decomposition rate. Decomposition of $\mathrm{N}_{d}$ is calculated with a similar equation by replacing $\mathrm{N}_{\mathrm{d}}$ for $\mathrm{C}_{\mathrm{d}}$. The temperature-dependent rate reduction factor $\left(\tau_{\mathrm{sl}}\right)$ is expressed as:

$\tau_{\mathrm{sl}}=Q_{10}^{\left(\frac{T_{\mathrm{sl}}-T_{\mathrm{opt}}}{10}\right)}$

where $\mathrm{Q}_{10}$ is the decomposition rate response to a $10^{\circ} \mathrm{C}$ increase in temperature. $T_{\text {opt }}$ is the optimum decomposition temperature and $T_{\mathrm{sl}}$ is temperature of soil layer sl calculated in the temperature submodel (Fig. 1). The decomposition rate reduction factor associated with suboptimal soil moisture $\left(m_{\mathrm{sl}}\right)$ is expressed as:

$m_{\mathrm{sl}}=\left(\frac{\theta_{\mathrm{sl}}}{\theta_{\mathrm{opt}}}\right)^{\lambda \mathrm{dec}}$ 
where $\theta_{\mathrm{sl}}$ and $\theta_{\mathrm{opt}}$ are soil water content in soil layer sl, and the optimum soil water content for decomposition, respectively, and $\lambda \mathrm{dec}$ is a tuning parameter.

Leaching depends on the infiltration rate of moisture according to

$\left(\frac{\delta \text { Ndiss }}{\delta t}\right)_{\text {leaching, } \mathrm{sl}}=f \times F w_{\mathrm{sl}} \times \frac{\mathrm{Ndiss}_{\mathrm{sl}}}{h_{\mathrm{sl}}}$

where $\left(\frac{\delta \text { Ndiss }}{\delta t}\right)_{\text {leaching,sl }}$ is Ndiss that penetrates a deeper layer. $\mathrm{Fw}_{\mathrm{sl}}$ is the rate of water infiltration in layer $\mathrm{sl}\left(\mathrm{m} \mathrm{s}^{-1}\right)$, calculated in the water cycle module (Fig. 1), and $\mathrm{f}$ is a proportionality constant that expresses the fraction of $\mathrm{N}$ in Ndiss, sl that is mobile (i.e. nitrate/all species of dissolved $\mathrm{N}$ ). Equation (24) quantifies leaching of $\mathrm{N}$ when $\mathrm{sl}=$ slMax. A constant fraction e of Ndiss is lost as gaseous emission $\left(\frac{\delta \mathrm{N}}{\delta t}\right)_{\text {emission. }}$.

$\left(\frac{\delta \mathrm{N}}{\delta t}\right)_{\text {emission, } \mathrm{sl}}=e \times \mathrm{Ndiss}_{\mathrm{sl}}$

Organic material slowly spreads due to bioturbation (i.e. mixing of material by soil animals). OGM assumes that the rate of transport of all litter types is equal, and decreases linearly with soil depth down to $1 \mathrm{~m}$ :

$\left(\frac{\delta \mathrm{C}}{\delta t}\right)_{\text {pert }, \mathrm{d}, \mathrm{sl}}=\mathrm{c}_{\text {pert }} \times\left(1.0-\right.$ depth $\left._{\mathrm{sl}}\right) \times \mathrm{C}_{\mathrm{d}, \mathrm{sl}}$

where $C_{d}$ expresses a $C$ decomposition pool (labile or recalcitrant). Perturbation in the $\mathrm{N}$ pools $\left(\mathrm{N}_{\mathrm{d}}\right.$ for $\left.\mathrm{d}=\{0,1\}\right)$ is described with a similar equation by replacing $C_{d}$ by $N_{d}$. Depth $_{\text {sl }}$ is the distance from soil surface to the center of soil layer $\mathrm{sl}$, and $\mathrm{c}_{\text {pert }}$ is the rate of perturbation at the surface.

\subsection{Model application}

\subsubsection{Initialization}

Soil initial conditions for the top $0-60 \mathrm{~cm}$ in INT and EXT were derived from site-specific measurements of soil properties (bulk density, organic carbon fraction, $\mathrm{C}: \mathrm{N}$ ratio and porosity). These were used to initialize associated parameters in the model (i.e. the model was not set to equilibrium). An exponential fit was used to estimate soil properties in 60-100 cm depth from available measurements above. Uncertainty limits of vegetation and model parameters were derived from published values, and tuning parameters were given uniform a-priori uncertainty ranges. Parameters such as altitude or heat properties of soil components remained fixed. We assumed that plant functional types (e.g. legumes and grasses) and site characteristics in INT and EXT were similar. Therefore, vegetation and model parameter values were equal.

\subsubsection{Calibration}

Uncertainty distributions were estimated for the different parameters that were previously described. In the context of this analysis, the use of a-priori knowledge was limited to estimates of minimum and maximum probable parameter values that are presented in literature. The model was applied repeatedly where parameter values were changed with each model call. Note that a model call in this context consists of two simulations: INT and EXT. After each model call, the performance of the model was evaluated considering a suite of criteria, for which information is available (e.g. soil moisture, root biomass, LAI, etc.). This performance was given a score, that was calculated as the sum of the coefficient of variation of $\operatorname{RMSE}\left(\mathrm{CV}_{\mathrm{RMSE}}=\mathrm{RMSE} /\left(x_{\max }-x_{\min }\right)\right.$, where RMSE $=\sqrt{ }\left(\Sigma(\mathrm{y}-\mathrm{x})^{2} / \mathrm{n}\right), x=$ measured, $y=$ modeled) over the criteria. The advantage of using $C_{\text {RMSE }}$ as a performance quantifier is that it is unit independent and thus allows a comparison of multiple criteria. When we present optimized model results, we are using parameter values that are associated with model calls that delivered the smallest value of $\Sigma \mathrm{CV}_{\mathrm{RMSE}}$ in an extensive series (thousands) of model calls.

\subsubsection{Evaluation}

The model was evaluated using graphic comparisons of modeled and measured estimates. We further used some classic statistical parameters to describe goodness-of-fit of the model. For evaluation of individual measurement types, we have used normalized root mean square error (NRMSE) and coefficient of determination $\left(R^{2}\right)$. NRMSE (=RMSE/ $\mathrm{X}_{\text {average }}$ ) is similar to $\mathrm{CV}_{\mathrm{RMSE}}$, but since it is more commonly used in scientific literature, NRMSE facilitates comparison with other publications.

\subsubsection{Climate and management scenarios}

The climate change signal used to specify the scenarios was obtained from a simulation with the Climate HighResolution Model (CHRM) (Vidale et al., 2003) completed in the framework of the PRUDENCE project (Christensen and Christensen, 2007). Corresponding changes in monthly precipitation amounts, average length of wet and dry spells, minimum and maximum temperature, temperature standard deviation, and solar radiation nominally valid for the end of the 21st century already given in Lazzarotto et al. (2010) are reproduced here in Table 3 for the sake of clarity.

Time series of synthetic daily weather data corresponding to the different scenarios, which were later adopted as an input to OGM, were developed using the LARSWG stochastic weather generator (Semenov, 2007). For our application, LARSWG was calibrated using 27 years of high-quality daily weather observations spanning the period 1981-2007 from an operational weather station (Wynau, $7^{\circ} 47^{\prime} \mathrm{E}, 47^{\circ} 15^{\prime} \mathrm{N}, 422 \mathrm{~m}$.a.s.l.) close to our study site and provided by the Swiss Federal Office for Meteorology and Climatology (MeteoSwiss). For each of the three scenarios, the parameters defining the stochastic generation process 
Table 3. Changes $(\Delta)$ in monthly climate statistics between 2071-2100 and 1961-1990 (reference) simulated by the Climate High Resolution Model for the Swiss Plateau under the assumption of an A2 emissions scenario. Changes in mean precipitation rate $(P)$, duration of wet $\left(\tau_{\text {wet }}\right)$ and dry $\left(\tau_{\text {dry }}\right)$ spells, global radiation $(\mathrm{GR})$ and inter-annual standard deviation of air temperature $\left(\sigma_{T}\right)$ are relative; changes in daily maximum $\left(T_{\max }\right)$ and minimum $\left(T_{\min }\right)$ air temperature are absolute.

\begin{tabular}{llllllll}
\hline Month & $\begin{array}{l}\Delta P / P \\
(-)\end{array}$ & $\begin{array}{l}\Delta \tau_{\text {wet }} / \tau_{\text {wet }} \\
(-)\end{array}$ & $\begin{array}{l}\Delta \tau_{\text {dry }} / \tau_{\text {dry }} \\
(-)\end{array}$ & $\begin{array}{l}\Delta T_{\max } \\
\left({ }^{\circ} \mathrm{C}\right)\end{array}$ & $\begin{array}{l}\Delta T_{\min } \\
\left({ }^{\circ} \mathrm{C}\right)\end{array}$ & $\begin{array}{l}\Delta \sigma_{T} / \sigma_{T} \\
(-)\end{array}$ & $\begin{array}{l}\Delta \mathrm{GR} / \mathrm{GR} \\
(-)\end{array}$ \\
\hline Jan & 1.1 & 0.91 & 0.65 & 3.51 & 3.07 & 0.8 & 1.07 \\
Feb & 1.44 & 1.19 & 0.73 & 2.57 & 2.11 & 0.79 & 0.98 \\
Mar & 1.26 & 1.01 & 0.7 & 1.93 & 1.38 & 0.96 & 1 \\
Apr & 0.99 & 0.86 & 1.11 & 2.99 & 2.15 & 1.18 & 1.14 \\
May & 0.77 & 0.53 & 1.23 & 3.58 & 2.49 & 1.11 & 1.16 \\
Jun & 0.72 & 0.72 & 1.75 & 4.07 & 2.89 & 1.33 & 1.13 \\
Jul & 0.53 & 0.77 & 2.21 & 5.64 & 3.49 & 1.23 & 1.14 \\
Aug & 0.69 & 0.75 & 1.79 & 7.05 & 4.28 & 1.13 & 1.17 \\
Sep & 0.72 & 0.86 & 1.34 & 5.95 & 4 & 1 & 1.12 \\
Oct & 0.98 & 0.81 & 1.08 & 4.4 & 3 & 1.11 & 1.16 \\
Nov & 0.66 & 0.82 & 1.34 & 3.39 & 1.64 & 0.96 & 1.32 \\
Dec & 1.06 & 1.15 & 0.92 & 3.37 & 2.58 & 0.79 & 1.23 \\
\hline
\end{tabular}

were adjusted using the anomalies specified in Table 3 (for details see Semenov, 2007). These adjustments were assumed to be valid in 2100; linear interpolation in time was internally applied to infer a transient evolution of the monthly climate (Lazzarotto et al., 2010).

Ultimately, 110 years of synthetic weather data were generated for each scenario. In addition, a 110-year time series was also generated without modification of the calibration parameters. This simulation provides data statistically consistent with the current climate and was used in the socalled EQUIL runs (Table 4). We further used scenarios with changes in the precipitation regime during April to October (Growing Season Drought, GSD) or changes in precipitation, temperature and solar radiation (A2-370), both with atmospheric $\mathrm{CO}_{2}$ concentration fixed at $370 \mathrm{ppm}$, and a scenario with changes in climate and $\mathrm{CO}_{2}$ concentrations increasing to $860 \mathrm{ppm}$ by 2100 (A2-860) according to predictions of atmospheric $\mathrm{CO}_{2}$ by the Bern-CC model for the $\mathrm{A} 2$ emission pathway (see Appendix I in IPCC, 2000).

Management events were forecast for each year in the period 2010-2100, by randomly picking a year between 2001 and 2010, and assuming that the recorded harvest/manuring events in this year are repeated in the forecast year. Combining two management scenarios (INT/EXT) and four scenarios for climatic change (EQUIL/GSD/A2-370/A2-860), delivered 8 model runs summarized in Table 4. Linear Regression lines were fit to the last decade of soil $\mathrm{C}$ to determine sequestration, where soil $\mathrm{C}$ at 1 January 2001 and its fitted value in 2101 were used as indicators.

\section{Results}

\subsection{Model evaluation and performance (2002-2010)}

Coefficients of determination $\left(R^{2}\right)$ of soil temperature ranged from 0.97 to 0.99 . Normalized root mean squared error (NRMSE) ranged from 0.05 to 0.07 (Table 5). Coefficients of determination $\left(R^{2}\right)$ of soil moisture ranged from 0.77 at $5 \mathrm{~cm}$ depth to 0.89 at $10 \mathrm{~cm}$ depth (Table 5; Fig. 2). NRMSE indicated a similar goodness of fit across different soil depths, with the best fit at $30 \mathrm{~cm}$ depth (NRMSE $=0.11$ ), and the least fit at $50 \mathrm{~cm}$ depth (NRMSE $=0.41)$. Dry periods in the summers were usually well captured by the model. We did find, however, that the level of moisture extraction tended to be slightly underestimated in the top soil, while overestimated in deeper soil (compare 5 and $10 \mathrm{~cm}$ soil depth with 30 and $50 \mathrm{~cm}$ soil depth in Fig. 2).

According to the model simulation, legumes contributed $\sim 22 \%$ to LAI in EXT (average for $100 \mathrm{yr}$ ), typically fluctuating between $\sim 5 \%$ and $\sim 35 \%$ (Fig. 3). In contrast, legumes retained little leaf area in INT, which is in agreement with the situation in the field where clover had to be re-sown in 2006. The first harvest in each year was commonly underestimated and subsequent cuts were slightly overestimated due to an effect of growth phase (vegetative growth vs. reproductive growth) that is not implemented in the model. Additionally, the use of a constant harvest efficiency caused inadequate prediction of the biomass extraction with individual cuts (for a review of harvest efficiency, see Ammann et al., 2007). The introduction of seasonal variability in growth rates and harvest efficiency could improve model predictions here, even though such inclusion would involve estimation of several additional model parameters. 
Table 4. Climate scenarios (reps. for randomized realizations of a climate scenario).

\begin{tabular}{|c|c|c|c|c|}
\hline \# & Scenario & Climate scenario & Period & Reps \\
\hline 1 & EQUIL & Climate equilibrium & $2010-2100$ & 1 \\
\hline 2 & GSD & Growing season drought & $2010-2100$ & 5 \\
\hline 3 & A2-370 & Full A2 climate scenario, but with $\mathrm{CO}_{2}$ concentration kept constant at $370 \mathrm{ppm}$. & $2010-2100$ & 5 \\
\hline 4 & A2-860 & Full A2 climate scenario, with $\mathrm{CO}_{2}$ concentration reaching $860 \mathrm{ppm}$. by the end of the century & $2010-2100$ & 5 \\
\hline
\end{tabular}

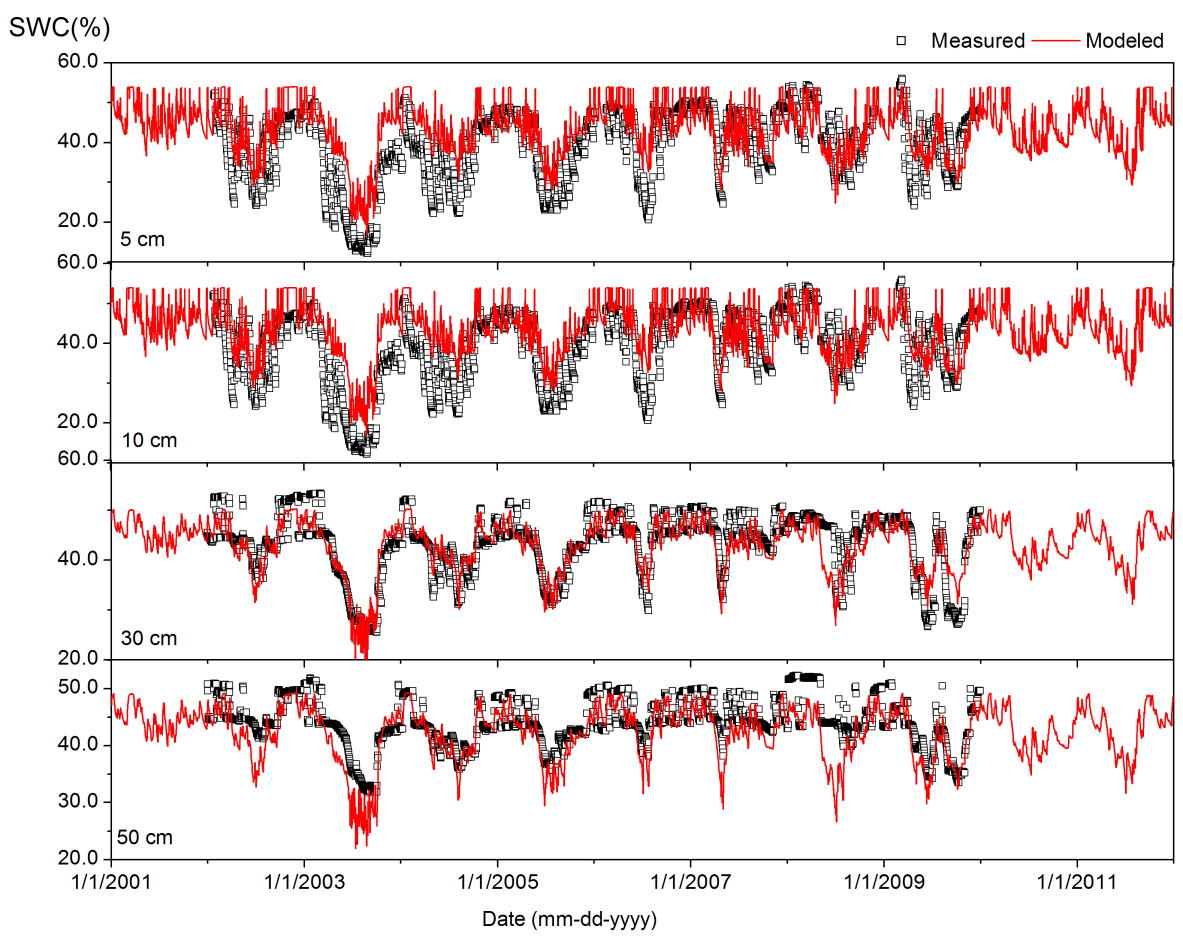

Fig. 2. Soil water content (SWC) expressed in \%VOL in increasing soil depths.

Modeled root biomass approximated measured amounts in 2004 (Fig. 3; Table 5). Although not directly verified, there are indications that seasonal dynamics were plausible. For instance, Garcia-Pausas et al. (2011) measured maximum seasonal fluctuations in grass root biomass of approximately $30 \%$ in a Pyrenees mountain grassland (compare with Fig. 3).

Aboveground litter production was 527$585 \mathrm{~g} \mathrm{DW} \mathrm{m}^{-2} \mathrm{yr}^{-1}$ (EXT...INT), which was high compared to data of Hitz et al. (2001) who found values of $80-400 \mathrm{~g} \mathrm{C} \mathrm{m}^{-2} \mathrm{yr}^{-1}$ in grasslands that produce 100 to $300 \mathrm{~g} \mathrm{DW} \mathrm{m}^{-2}$ with individual harvests. Note that aboveground litter here does not include harvest remnants. Belowground litter production was $758-809 \mathrm{~g} \mathrm{DW} \mathrm{m}^{-2} \mathrm{yr}^{-1}$ (EXT...INT).

Turnover time of grass roots was 1.4 years, whereas Van der Krift and Berendse (2002) estimated root turnover times for some typical grass species (Lolium perenne, Arrhenatherum elatius, Molinia caerulea, Nardus stricta) in the range from 0.8 to 1.11 years. Longer turnover times (3.3-
$11.5 \mathrm{yr}$ ) were found in sub-alpine and alpine grasslands by Hitz et al. (2001).

\subsubsection{Distribution of roots and soil C (2001-2006)}

Root biomass in 2004 was slightly underestimated in EXT (modeled: $0.47 \mathrm{~kg} \mathrm{DW} \mathrm{m}^{-2}$; measured $0.49 \mathrm{~kg} \mathrm{DW} \mathrm{m}^{-2}$ ) and in INT (modeled: $0.52 \mathrm{~kg} \mathrm{DW} \mathrm{m}^{-2}$; measured $\left.0.58 \mathrm{~kg} \mathrm{DW} \mathrm{m}^{-2}\right)$. It was particularly underestimated in the INT topsoil ( $0-5 \mathrm{~cm}$, modeled: $5.9 \mathrm{mg}_{\mathrm{DW}} \mathrm{g}_{\text {soil }}^{-1}$; measured $\left.7.1 \pm 5.2 \mathrm{mg}_{\mathrm{DW}} \mathrm{g}_{\text {soil }}^{-1}\right)$, whereas root biomass density in the EXT topsoil $(0-5 \mathrm{~cm})$ was slightly overestimated (modeled: $5.3 \mathrm{mg}_{\text {DW }} \mathrm{g}_{\text {soil }}^{-1} ; \quad$ measured $4.0 \pm 3.3 \mathrm{mg}_{\text {DW }} \mathrm{g}_{\text {soil }}^{-1}$ ). Note, however, that measurement errors in root biomass typically exceed the lack-of-fit of the model.

Soil organic carbon $(0-45 \mathrm{~cm})$ in 2006 was slightly underestimated in INT (modeled: $14.7 \mathrm{~kg} \mathrm{~m}^{-2}$; measured: $14.8 \pm 1.4 \mathrm{~kg} \mathrm{~m}^{-2}$ ), and overestimated in EXT (modeled: $15.3 \mathrm{~kg} \mathrm{~m}^{-2}$; measured $14.3 \mathrm{~kg} \mathrm{~m}^{-2}$ ). 


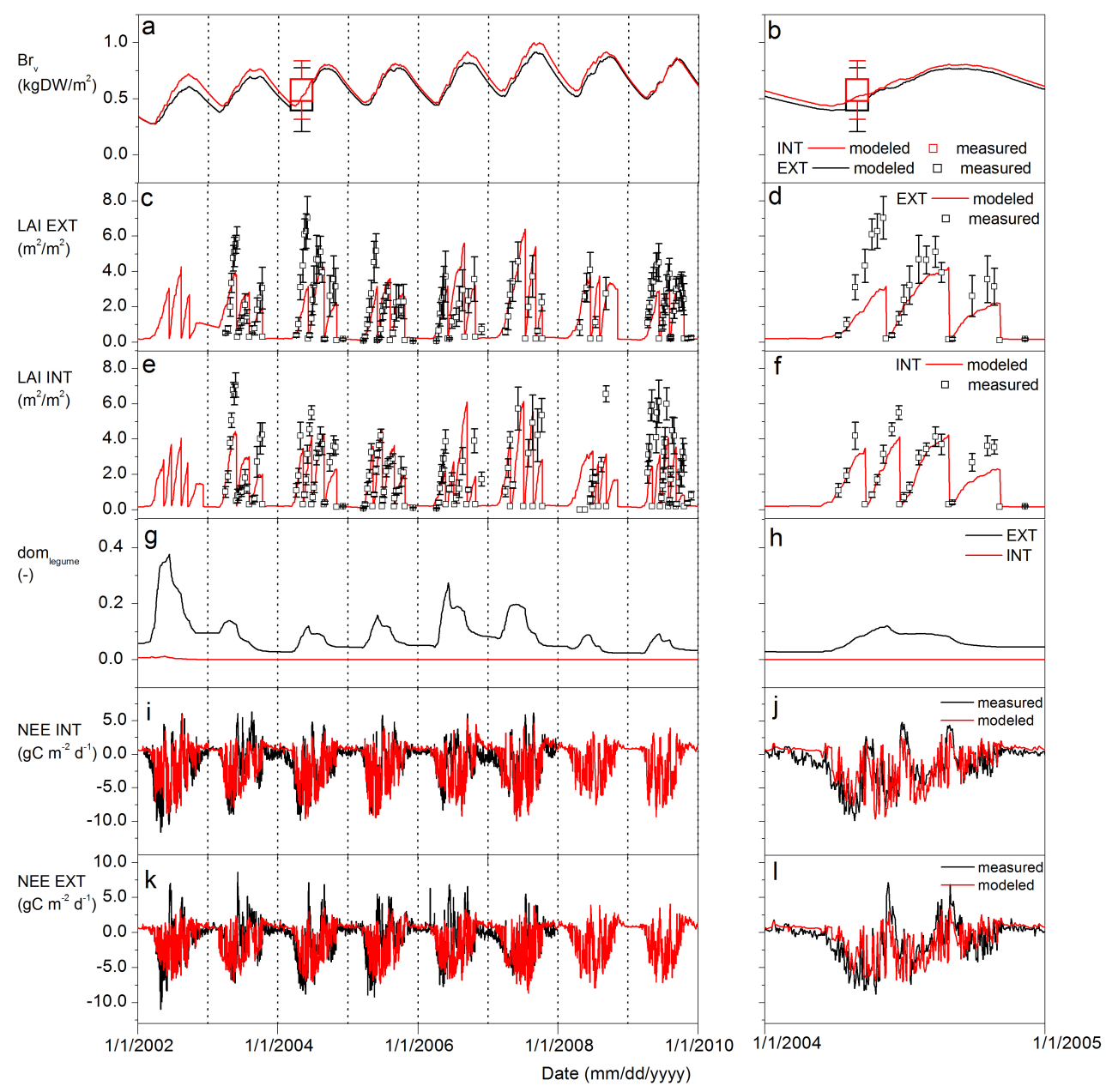

Fig. 3. Simulation and measurement results for grassland at Oensingen under extensive management (EXT) and intensive management (INT) at multi-annual (left panels) and annual (right panels) time scales. (a, b) measured and modeled sum of root biomass (Br, vertical bars indicate \pm se); (c-f) measured and modeled LAI; $(\mathbf{g}, \mathbf{h})$ dominance of leguminous species in terms of foliage cover (dom legumes); (i-l) measured and modeled net ecosystem exchange (NEE). Corresponding performance criteria are shown in Table 5.

Modeled carbon concentration had increased from $3.14 \%$ to $3.85 \%$ (EXT) and from $3.10 \%$ to $4.04 \%$ (INT) in the upper $5 \mathrm{~cm}$, from $3.15 \%$ to $3.28 \%$ (EXT) and from $3.05 \%$ to $3.16 \%$ (INT) between $5-10 \mathrm{~cm}$ depth. Small decreases were modeled in deeper layers (up to $0.14 \%$ ) in both INT and EXT with a maximum decrease at $10-20 \mathrm{~cm}$ depth. The distribution of $\mathrm{C}$ across depth was well captured by the model $\left(R^{2}=0.99, \mathrm{RMSE}=0.13-0.21 \mathrm{INT} / \mathrm{EXT}\right)$. Concentrations of $\mathrm{C}$ increased in the top $10 \mathrm{~cm}$ of soil, but decreased below $10 \mathrm{~cm}$ during 10 years of simulation.

\subsubsection{Carbon balance (2001-2010)}

The model was accurate for cumulative and inter-seasonal NEE in INT (Table 5), which indicated that the magnitude of NPP, respiration, and cumulative NPP + respiration over time were simulated accurately. Cumulative $\mathrm{CO}_{2}$ fluxes were overestimated by $25 \%$ in EXT. Harvests were slightly underestimated in EXT but overestimated in INT. Soil in EXT started to lose $\mathrm{C}$ approximately 3 years after establishment. These losses had not stabilized in 10 years. Biomass reached a long-term average of $714 \mathrm{~g} \mathrm{DW} \mathrm{m}^{-2}$ in EXT (belowground biomass: $620 \mathrm{~g} \mathrm{DW} \mathrm{m}^{-2}$; aboveground biomass: $94 \mathrm{~g} \mathrm{DW} \mathrm{m}^{-2}$ ) and $751 \mathrm{~g} \mathrm{DW} \mathrm{m}^{-2}$ in INT (belowground biomass: $664 \mathrm{~g} \mathrm{DW} \mathrm{m}^{-2}$; aboveground biomass: $87 \mathrm{~g} \mathrm{~m}^{-2}$ ) after approximately 4 to 5 years (EXT and INT). Yet, stabilization of soil $\mathrm{C}$ was not completed until several decades in both INT and EXT (see Sect. 3.2.).

\subsection{Carbon sinks in 2001-2100}

Differences in soil $\mathrm{C}$ between climate scenarios became evident approximately 20 years after establishment (Fig. 5). Scenarios that involved increasing concentrations of atmospheric $\mathrm{CO}_{2}$, in particular A2-860, led to higher soil C than the stationary climate scenario EQUIL. Differences between 
Table 5. Model performance on soil, biomass, and carbon budget parameters for 2002-2010. Note that only pairs of modeled and measured values are included in cumulative and average values to facilitate comparisons. Sums of measured NEE, gap-filled with annual averages, are shown in brackets. Criteria for goodness of fit are given when $n>1$.

\begin{tabular}{|c|c|c|c|c|c|c|c|}
\hline \multirow[t]{2}{*}{ Variable } & \multirow[t]{2}{*}{ Field } & \multicolumn{2}{|c|}{ Average } & \multicolumn{2}{|c|}{ Cumulative 2002-2010 } & \multicolumn{2}{|c|}{ Goodness of fit } \\
\hline & & measured & modeled & measured & modeled & $R^{2}$ & NRMSE \\
\hline Temperature $2 \mathrm{~cm}\left({ }^{\circ} \mathrm{C}\right)$ & INT & 10.6 & 10.6 & - & - & 0.97 & 0.06 \\
\hline Temperature $5 \mathrm{~cm}\left({ }^{\circ} \mathrm{C}\right)$ & INT & 10.6 & 10.6 & - & - & 0.98 & 0.05 \\
\hline Temperature $10 \mathrm{~cm}\left({ }^{\circ} \mathrm{C}\right)$ & INT & 10.6 & 10.6 & - & - & 0.98 & 0.05 \\
\hline Temperature $30 \mathrm{~cm}\left({ }^{\circ} \mathrm{C}\right)$ & INT & 10.7 & 10.7 & - & - & 0.98 & 0.05 \\
\hline Temperature $50 \mathrm{~cm}\left({ }^{\circ} \mathrm{C}\right)$ & INT & 10.6 & 10.7 & - & - & 0.97 & 0.07 \\
\hline Moisture $5 \mathrm{~cm}$ (\%VOL) & INT & 38.6 & 42.4 & - & - & 0.77 & 0.16 \\
\hline Moisture $10 \mathrm{~cm}(\% \mathrm{VOL})$ & INT & 40.9 & 42.1 & - & - & 0.89 & 0.12 \\
\hline Moisture $30 \mathrm{~cm}$ (\%VOL) & INT & 43 & 42.7 & - & - & 0.87 & 0.11 \\
\hline Moisture $50 \mathrm{~cm}$ (\%VOL) & INT & 44.1 & 41.9 & - & - & 0.82 & 0.41 \\
\hline \multirow[t]{2}{*}{$\operatorname{LAI}\left(\mathrm{m}^{2} \mathrm{~m}^{-2}\right)$} & INT & $2.06 \pm 0.45$ & 2.15 & - & - & 0.35 & 0.26 \\
\hline & EXT & $2.03 \pm 0.61$ & 1.98 & - & - & 0.61 & 0.19 \\
\hline Long-term legume & INT & - & $0 \%$ & - & - & - & - \\
\hline dominance $(-)$ & EXT & - & $22 \%$ & - & - & - & - \\
\hline Root mass profile 2004 & INT & $1.55 \pm 1.01$ & 1.28 & - & - & 0.99 & 0.57 \\
\hline$\left(\mathrm{mg} \mathrm{DW} \mathrm{g} \mathrm{g}^{-1}\right.$ soil) & EXT & $1.01 \pm 0.76$ & 1.14 & - & - & 0.99 & 0.54 \\
\hline Root biomass 2004 & INT & $0.58 \pm 0.26$ & 0.52 & - & - & - & - \\
\hline$\left(\mathrm{kg} \mathrm{DW} \mathrm{m}^{-2}\right)$ & EXT & $0.49 \pm 0.29$ & 0.47 & - & - & - & - \\
\hline \multirow[t]{2}{*}{ SOC $2006(\%)$} & INT & $2.93 \pm 0.35$ & 2.98 & - & - & 0.99 & 0.13 \\
\hline & EXT & $2.74 \pm 0.32$ & 2.86 & - & - & 0.99 & 0.21 \\
\hline NEE & INT & 1.06 & 0.98 & $2.3(4.1)$ & $2.1(3.8)$ & 0.68 & 0.13 \\
\hline$\left(\mathrm{gCm}^{-2} \mathrm{~d}^{-1}\right)$ or $\left(\mathrm{kgCm}^{-2}\right)$ & EXT & 0.66 & 0.84 & $1.4(2.5)$ & $1.8(3.2)$ & 0.58 & 0.11 \\
\hline \multirow[t]{2}{*}{ Harvest $\left(\mathrm{kg} \mathrm{DW} \mathrm{m}^{-2}\right)$} & INT & 0.19 & 0.19 & 5.3 & 5.4 & 0.54 & 0.22 \\
\hline & EXT & 0.23 & 0.20 & 4.8 & 4.3 & 0.49 & 0.26 \\
\hline
\end{tabular}

GSD/A2-370 scenarios and EQUIL occurred later. In EXT, losses of $\mathrm{C}$ were predicted to continue throughout the century and for all climate scenarios, except for A2-860, for which soil $\mathrm{C}$ loss stopped after 50 years and afterwards turned into an increase until the end of simulation. INT accumulated C during the first 45 years after establishment with all scenarios, and afterwards soil $\mathrm{C}$ remained nearly constant except for A2-860 where $\mathrm{C}$ accumulated throughout the century. Hence, towards the end of the simulation period, $\mathrm{C}$ dynamics were effectively dominated by vegetation responding to different climatic drivers.

Compared to EQUIL, NPP was lower in the GSD scenario (INT: $-3.4 \%$, EXT: $-4.4 \%$ ). NPP increased in the A2-370 scenario (INT: $+3.1 \%$, EXT: $+3.4 \%$ ) and in the A2860 scenario as well (INT: $+19.2 \%$, EXT: $+25.2 \%$ ). Harvested biomass was lower by a similar fraction in either management system in the GSD scenario (INT: $-5.4 \%$, EXT: $-5.2 \%)$. Slightly higher harvests were predicted for the A2370 scenario (INT: $+3.1 \%$, EXT: $+3.5 \%$ ), while considerable increases were found for A2-870 (INT: $+7.5 \%$, EXT: $+14.2 \%$ ). Respiration decreased in the GSD scenario (INT: $-2.4 \%$, EXT: $-3.4 \%$ ), but was higher in the other scenarios (INT/A2-370: $+4.1 \%$, EXT/A2-370: $+5.1 \%$, INT/A2-860: $+7.5 \%$, EXT/A2-860: $+14 \%$ ).
Net $\mathrm{C}$ sequestration over 100 years was predicted for all of the INT scenarios (EQUIL: $+1.3 \mathrm{~kg} \mathrm{C} \mathrm{m}^{-2}$, GSD: $+1.2 \pm 0.1 \mathrm{~kg} \mathrm{C} \mathrm{m}^{-2}, \mathrm{~A} 2-370:+1.8 \pm 0.2 \mathrm{~kg} \mathrm{C} \mathrm{m}^{-2}, \mathrm{~A} 2-860$ : $+5.3 \pm 0.3 \mathrm{~kg} \mathrm{C} \mathrm{m}^{-2}$ ). Losses of soil $\mathrm{C}$ resulted for all EXT scenarios except A2-860 (EQUIL: $-3.1 \mathrm{~kg} \mathrm{Cm}^{-2}$; GSD: $-3.9 \pm 1.1 \mathrm{~kg} \mathrm{Cm}^{-2}$; A2-370: $-2.1 \pm 0.3 \mathrm{~kg} \mathrm{C} \mathrm{m}^{-2}$, A2-860: $+1.6 \pm 0.3 \mathrm{~kg} \mathrm{C} \mathrm{m}^{-2}$ ). Across all climate scenarios, there was a consistent and considerable difference between soil $\mathrm{C}$ sequestration in EXT and INT. Harvest and Respiration were tightly coupled to NPP in all the climate scenarios, the ratio of harvest/NPP (in $\mathrm{kg} \mathrm{C} / \mathrm{kg} \mathrm{C}$ ) over the total simulation period ranged from 27-30\% in EXT and 29$32 \%$ in INT (Fig. 5). Similarly, respiration/NPP ranged from $71-75 \%$ in EXT and from $71-74 \%$ in INT. Low respiration/NPP and harvest/NPP ratios were typically found for A2-860 in both INT and EXT. Highs were not so consistent, maximum harvest/NPP occurred in INT/EQUIL. Maximum respiration/NPP occurred in EXT/A2-370.

\subsubsection{Distribution of roots and soil $\mathrm{C}$ in 2001-2100}

Soil C increased mainly in the top $15 \mathrm{~cm}$ of the soil, whereas small losses occurred from 15 to $85 \mathrm{~cm}$. Losses of $\mathrm{C}$ in EXT/EQUIL stabilized after approximately 50 years. Until then, the model simulated $\mathrm{C}$ losses occurred particularly 


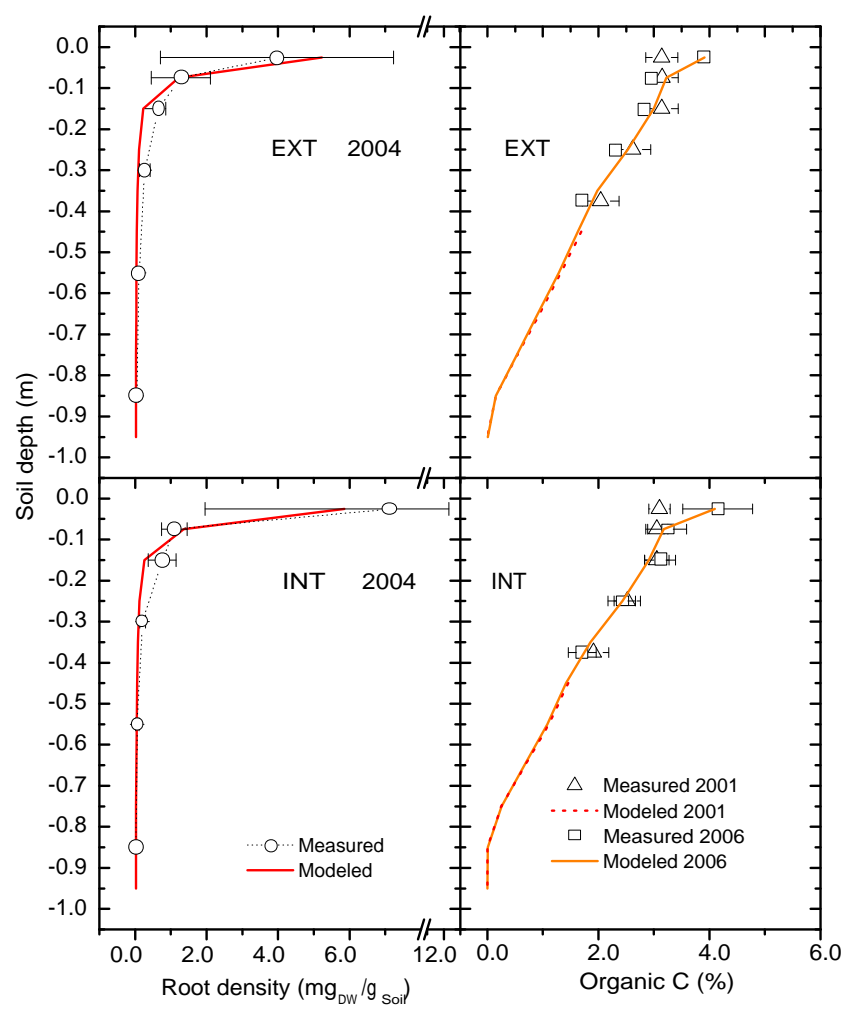

Fig. 4. Root density (left) and soil carbon concentration (right) for EXT (upper pane) and INT (lower pane). Measurements are given \pm se.

between 15 and $80 \mathrm{~cm}$ depth (Fig. 4), summing up to $\sim 1.5 \mathrm{~kg} \mathrm{C} \mathrm{m}^{-2}$ over the entire 100-year simulation period. Hence, with time the range of depth, where soil $\mathrm{C}$ loss occurred, shifted slightly downward (compare Fig. 4 with Fig. 6).

\section{Discussion}

\subsection{Long-term SOC}

Our simulation results indicate that SOC stabilizes in EQUIL and GSD scenarios for INT, while C loss in EXT had not come to a halt in 2100 . $\triangle$ SOC after land use conversion depends particularly on the balance of litter production, manure application, and decomposition rates. Litter production depends on moisture and temperature, but also on seasonal aspects such as foliage cover, root density, growth, and harvest efficiency. After a land use change, we can expect that litter production changes with growth rate. Decomposition of SOC depends foremost on a-biotic conditions, as well as quality and quantity of litter. SOC will therefore tend to increase or decrease depending on the new balance between litter fall and decomposition, until it stabilizes when the level of SOC has changed to such extend that litter and manure input equals decomposition.

The level of SOC, at which saturation occurs, is of importance to explain our simulation results. We found relative changes in SOC of $7.0 \%$ (INT) and $-14.7 \%$ (EXT), values that are lower than those given either by Poeplau et al. (2011) or IPCC (2000, table 1). While Poeplau et al. (2011) and IPCC (2000) review studies of lands that are exclusively managed in arable rotations, Oensingen had been under leyarable management before conversion. Leifeld et al. (2005) found substantially higher SOC in ley-arable managed soil. The Oensingen sites contained $18-20 \mathrm{~kg} \mathrm{C} \mathrm{m}^{-2}$ prior to conversion while IPCC (2000) assumes $\mathrm{SOC}=8 \mathrm{~kg} \mathrm{C} \mathrm{m}^{-2}$ for croplands, and the arable soils considered by Poeplau et al. (2011) contained merely $4.6 \pm 2.1 \mathrm{~kg} \mathrm{C} \mathrm{m}^{-2}$. High SOC in ley-arable managed soil may be particularly due to high litter input in ley seasons. Because litter input may have been of similar quantity prior to land use change, sequestration potentials after conversion to permanent grassland may depend strongly on manure-C input (see also Sect. 4.2).

We can also compare our results with those found by Riedo et al. (2000), who modeled 3 sites with typical characteristics: Bern (high productivity), Sion (dry), and Davos (high altitude). The PaSim model was used to estimate sequestration potentials under different management options (cutting or grazing) and climates. Assuming a scenario comparable with our A2-860 scenario (lower precipitation, higher temperatures, radiation intensity and concentrations of atmospheric $\mathrm{CO}_{2}$; T2pm), Riedo et al. (2000) found that soil $\mathrm{C}$ decreased by $\sim 5 \%$ for Bern and $\sim 10 \%$ for Sion, but increased $\sim 13 \%$ for Davos, relative to a reference simulation (TOP0) that involved higher atmospheric $\mathrm{CO}_{2}$ alone.

Our reference climate scenario (EQUIL) assumes that atmospheric $\mathrm{CO}_{2}$ concentrations remain constant, so we ran an additional simulation using a climate scenario in which only atmospheric $\mathrm{CO}_{2}$ increases, but temperature, precipitation and radiation remain constant. We found lower $\mathrm{C}$ contents by $4.4 \%$ in INT $\left(0.8 \mathrm{~kg} \mathrm{C} \mathrm{m}^{-2}\right)$ and by $4.8 \%$ in EXT $\left(1.0 \mathrm{~kg} \mathrm{C} \mathrm{m}^{-2}\right)$ compared to the reference scenario, which is very similar to results of Riedo et al. (2000) for Bern.

Our estimate indicates an average sink of $0.05 \mathrm{~kg} \mathrm{C} \mathrm{m}^{-2} \mathrm{yr}^{-1}$ in INT based on the difference between INT/EQUIL and EXT/EQUIL after 100 years. In comparison, Lal et al. (2007) estimated that introducing fertilization creates a sink for $\mathrm{C}$ of only $0.01-0.02 \mathrm{~kg} \mathrm{C} \mathrm{m}^{-2} \mathrm{yr}^{-1}$ on average, or conversion of arable land to pasture, a sink of $0.04-0.06 \mathrm{~kg} \mathrm{C} \mathrm{m}^{-2} \mathrm{yr}^{-1}$. While our findings in INT are very comparable with studies reviewed in Lal et al. (2007), we found substantially lower sequestration potentials in EXT.

The long-term simulations in Fig. 5 shows that the tendency observed during the first 10 years after conversion cannot generally be extrapolated beyond approximately 20 years. This has implications for the interpretation of field experiments that attempt to quantify possible long-term 


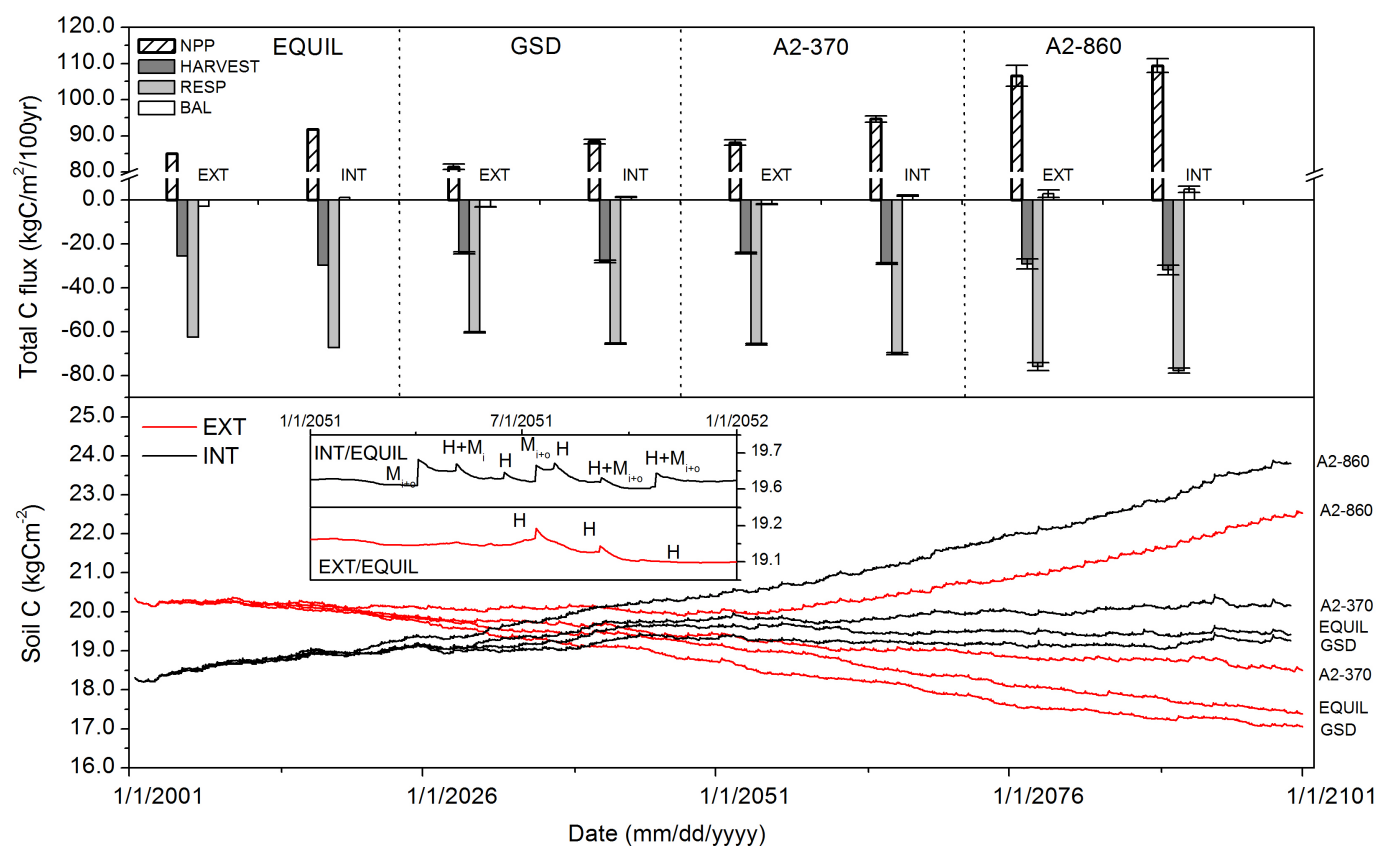

Fig. 5. Simulations of soil organic $\mathrm{C}$ (in $\mathrm{g} \mathrm{C} \mathrm{m}^{-2}$ ) between 2001-2100. Top panel: $\mathrm{C}$ budget 100 years after establishment of grassland. Bottom panel: Temporal C dynamics between 2001-2100 (inset: simulations of SOC between 2051-2052 for INT and EXT. Management activities are shown as $\mathrm{H}=$ harvest; $\mathrm{M}_{\mathrm{i}}$ and $\mathrm{M}_{\mathrm{i}+\mathrm{o}}=$ inorganic and organic plus inorganic manure application, respectively). Legend entries: $\mathrm{NPP}=$ Net Primary Productivity, Harvest $=$ extracted biomass, Resp $=$ heterotrophic respiration, Bal $=\mathrm{C}$ balance (soil + biomass) .

changes in SOC stock by sampling soil profiles over shorter time intervals (often directly after conversion).

We found that $\mathrm{C}$ accumulation initially occurs mainly in the top $10 \mathrm{~cm}$ of the soil, but increases to $\sim 15 \mathrm{~cm}$ in the course of the 100-year simulation. In agreement, Conant et al. (2001) found that SOC increments were observed particularly in the top $10 \mathrm{~cm}$ soil. It is very common that SOC is not measured beyond $30 \mathrm{~cm}$ depth. In fact, the average soil depth in studies reviewed by Conant et al. (2001) was only $32.2 \mathrm{~cm}$. However, we investigated how $\triangle \mathrm{SOC}$ changes with soil depth (Fig. 6) and found indications that reliable assessments of $\mathrm{C}$ sequestration potentials need to consider deeper layers, as root biomass turnover increases with root depth. The change in SOC with depth is considerable in the top $50 \mathrm{~cm}$ of the soil at least, and the simulations suggest $\mathrm{C}$ loss to occur below $40 \mathrm{~cm}$ depth in the EXT/EQUIL scenario, and $\mathrm{C}$ gains above. Hence considerable changes in $\mathrm{C}$ sequestration potentials can occur at levels deeper than are commonly measured, although depending on site management and history, the potentials for $\mathrm{C}$ accumulation at $>30 \mathrm{~cm}$ soil depth may be small.

\subsection{The importance of biomass turnover and manure application}

We found that $\mathrm{C}$ sequestration potentials differ considerably according to management intensity. In more detail, two processes are particularly important: biomass turnover and manure application.

The assumption that vegetation characteristics for a cohort (grass or clover) are the same regardless of management was inevitable because vegetation developments in INT and EXT would be equally well explained by plant characteristics (e.g. water use efficiency, biomass growth response to soil $\mathrm{N}$ ) as by abiotic conditions (soil water content, dissolved $\mathrm{N}$ in the soil) if vegetation parameters had been allowed to vary freely. However inevitably, this assumption introduces some uncertainties. The seed mixture that was used in EXT, for example, contained different and more species of grasses than the mixture that was used in INT and also contained herbs.

The use of equal biomass turnover rates in INT and EXT, in particular, may lead to an overestimation of biomass senescence and SOC in EXT, for which modeled cumulative NEE was $\sim 25 \%$ higher than measured NEE (Table 5: compare overestimation of NEE in EXT with underestimation of harvest in EXT). This overestimation is related to a considerable difference in "Sequestration efficiency" $\left(S_{\mathrm{e}}=1.0-\right.$ harvest/NEE) between INT and EXT. Measurements indicate that $S_{\mathrm{e}}$ is considerably lower in EXT (0.15) than in INT 


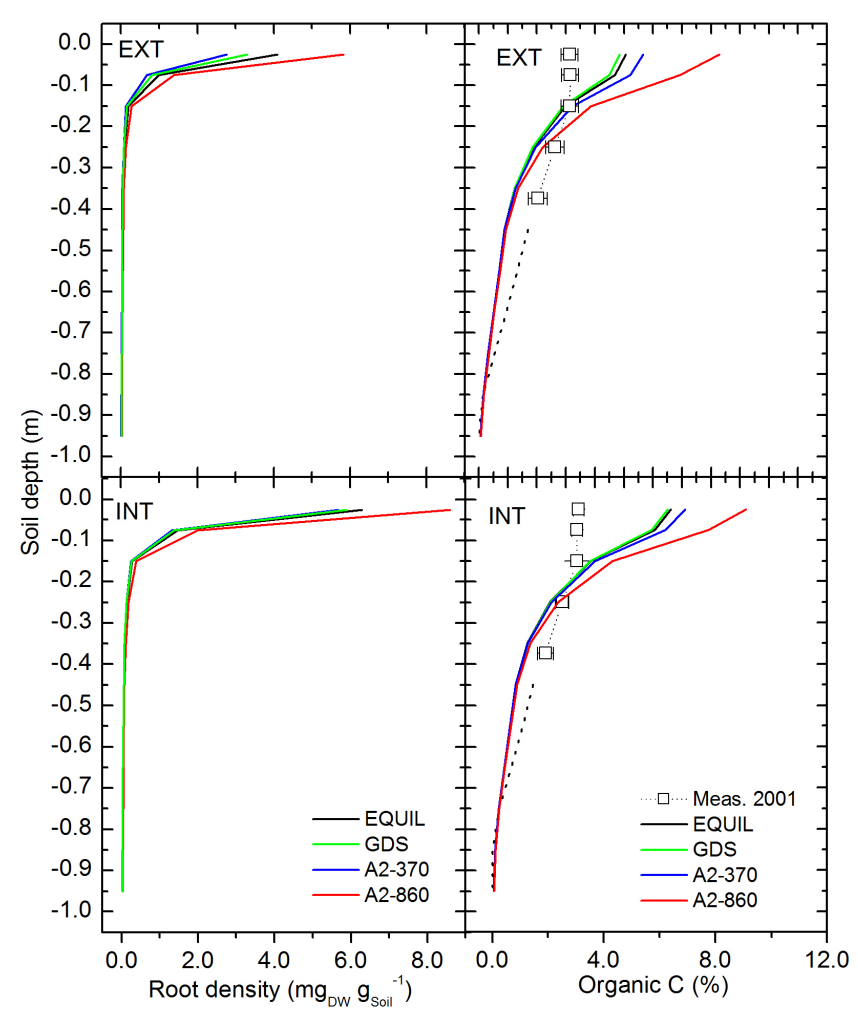

Fig. 6. Simulated root density (left) and soil carbon (right) for EXT (upper pane) and INT (lower pane) in 2001 and 2100 under different climate and management scenarios. Measurements in 2001 are given \pm se.

(0.44), whereas this ratio is nearly equal in the simulations (EXT: 0.37, INT: 0.40). The difference is consistent with a slight underestimation $\left(0.1 \mathrm{~kg} \mathrm{C} \mathrm{m}^{-2}\right)$ of soil $\mathrm{C}$ in 2006 in INT, and a considerable overestimation $\left(1.0 \mathrm{~kg} \mathrm{C} \mathrm{m}^{-2}\right)$ of modeled SOC in 2006 in EXT. Hence it is unlikely that this lack of fit is related to measurement uncertainty.

This finding is unexpected because litter in unfertilized (nitrogen poor) grassland is generally thought to decompose slower (Aerts et al., 2003). Instead a converse effect seems to dominate in EXT. For example, higher aboveground allocation could be sustained due to lower (belowground) senescence. There are two known plant adaptations to nutrient poor conditions that lead to reduced senescence (Chapin, 1980; Louault et al., 2005). One response is instantaneous: senescence of both root and shoot increases with protein concentration in the plant tissues. Moreover, root longevity may be extended due to mycorrhizal symbiosis that is stronger in nutrient poor conditions. A second response is genetic: slow-growing species are better capable to compete in nutrient poor conditions by increased longevity of biomass (Chapin, 1980).

Manure application increases soil $\mathrm{C}$ indirectly via higher plant assimilation and litter production as well as directly through manure-C amendment (Leifeld and Fuhrer, 2010;
Jones et al., 2006). We tested how these two mechanisms contribute to the difference that we found with four slightly different model applications. Excluding manurederived $\mathrm{C}$ from our INT/EQUIL simulation (Table 4; i.e. only manure- $\mathrm{N}$ is spread among soil deposition pools according to Eq. 17) would lead to a $1.0 \mathrm{~kg} \mathrm{C} \mathrm{m}^{-2}$ lower soil $\mathrm{C}$ after 100 years (i.e. it reduces $\mathrm{C}$ increment from $1.1 \mathrm{~kg} \mathrm{C} \mathrm{m}^{-2}$ to $0.1 \mathrm{~kg} \mathrm{C} \mathrm{m}^{-2}$ ). A similar difference is found when all manure-bound $\mathrm{N}$ is applied with inorganic fertil$\operatorname{izer}(\Delta \mathrm{SOC}=\sim 0.0)$. The results indicate that $\sim 60 \%$ of the manure effect on soil $\mathrm{C}$ over a 100 -year simulation can be attributed to import of $\mathrm{C}$.

\section{Conclusions}

We have analyzed how management and global warming interact in two grassland systems established on former cropland in Central Switzerland. The aim was to investigate the long-term relationship between climate, soil $\mathrm{C}$ storage and management during a 100-year simulation period following establishment in 2002. The simulation results lead to the following conclusions:

1. Intensive management (i.e. fertilization) drives the SOC dynamics until $\sim 45$ years after sowing, while climate change determines soil $\mathrm{C}$ in the longer term.

2. Previous arable land use has to be specified exactly to estimate potential sequestration of $\mathrm{C}$. Prior to conversion, Oensingen grasslands had high SOC due to the use of ley-arable rotations as compared to an exclusively arable cropping system.

3. A larger fraction of the increase in soil organic $\mathrm{C}$ in fertilized plots originates from applied manure, compared to the input from increased amounts of plant litter.

4. After grassland establishment, soil $\mathrm{C}$ increases mainly in the top $10 \mathrm{~cm}$ of soil, but in the course of 100 years, soil $\mathrm{C}$ increments are observed down to $15 \mathrm{~cm}$.

5. Comparing the Oensingen site with conditions that are dominant in Switzerland, C sequestration potentials may be lower at warm low-precipitation sites, but higher at cooler and wet high-altitude sites.

Acknowledgements. This work was funded by the Swiss national Science Foundation in the framework of the NCCR Climate project AGRISK. We further thank Mikhail Semenov for the use of his LARS Weather Generator, as well as MeteoSwiss for making climate records publically available.

Edited by: G. Wohlfahrt 


\section{References}

Aerts, R., De Caluwe, H., and Beltman, B.: Plant community mediated vs. nutritional controls on litter decomposition rates in grasslands, Ecology, 84, 1398-3208, 2003.

Aeschlimann, U., Nösberger, J., Edwards, T. J., Schneider, M. K., Richer, M., and Blum, H.: Responses of net ecosystem CO2 exchange in managed grassland to long-term $\mathrm{CO}_{2}$ enrichment, $\mathrm{N}$ fertilization and plant species, Plant Cell Environ., 28, 823-833, 2005.

Ainsworth, E. A., Davey, P. A., Hymus, G. J., Osborne, C. E., Rogers, A., Blum, H., Nosberger, J., and Long, S. E.: Is stimulation of leaf photosynthesis by elevated carbon dioxide concentration maintained in the long term? A test with Lolium perenne grown for 10 years at two nitrogen fertilization levels under Free Air $\mathrm{CO}_{2}$ Enrichment (FACE), Plant Cell and Environ., 26, 705714, 2003.

Ammann, C., Flechard, C. R., Leifeld, J., Neftel, A., and Fuhrer, J.: The carbon budget of newly established grassland depends on management intensity, Agric. Ecosyst. Environ., 121, 5-20, 2007.

Ammann, C., Spirig, C., Leifeld, J., and Neftel, A.: Assessment of the nitrogen and carbon budget of two managed temperate grassland fields, Agric. Ecosyst. Environ., 133, 150-162, 2009.

Casella, E. and Soussana, J.-F.: Long-term effects of $\mathrm{CO}_{2}$ enrichment and temperature increase on the carbon balance of a temperate grass sward, J. Exp. Bot., 48, 1309-1321, 1997.

Chapin, F. S.: The mineral nutrition of wild plants, Ann. Rev. Ecol. Syst., 11, 233-260, 1980.

Christensen, J. H. and Christensen, O. B.: A summary of the PRUDENCE model projections of changes in European climate by the end of this century, Clim. Change, 81, 7-30, 2007.

Conant, R. T., Paustian, K., and Elliot, E. T.: Grassland management and conversion into grassland: effects on soil Carbon, Ecol. Appl., 11, 343-355, 2001.

Conant, R. T., Ogle, S. M., Paul, E. A., and Paustian, K.: Measuring and monitoring soil organic carbon stocks in agricultural lands for climate mitigation, Front Ecol. Environ., 9, 169-173, 2011.

De Bruijn, A. M. G. and Butterbach-Bahl, K.: Linking carbon and nitrogen mineralization with microbial responses to substrate availability - the DECONIT model, Plant Soil, 328, 271-290, 2010.

FAO, ISRIC and ISSS: World Reference Base for Soil Resources, Food and Agriculture Organization of the United Nations, Rome, 1998.

Garcia-Pausas, J., Casals, P., Romanyà, J., Vallecillo, S., and Sebastià, M.-T.: Seasonal patterns of belowground biomass and productivity in mountain grasslands in the Pyrenees, Plant Soil, 340, 315-326, 2011.

Gerwitz, A. and Page, E. R.: An empirical mathematical model to describe plant root systems, J. Appl. Ecol., 11, 773-782, 1974.

Ham, J., Heilman, J. L., and Lascano, R. J.: Determination of soil water evaporation and transpiration from energy balance and stem flow measurements, Agric. For. Met., 52, 287-301, 1990.

Hitz, C., Egli, M., and Fitze, P.: Below-ground and above-ground production of vegetational organic matter along a climosequence in alpine grasslands, J. Plant Nutr. Soil Sci., 164, 389-397, 2001.

IPCC Intergovernmental Panel on Climate Change: Land use, landuse change and forestry, Cambridge, UK, Cambridge University Press, 2000
IPCC: Climate Change 2007: The Physical Science Basis, Contribution of Working Group I to the Fourth Assessment Report of the Intergovernmental Panel on Climate Change, edited by: Solomon, S., Qin, D., Manning, M., Chen, Z., Marquis, M., Averyt, K. B., Tignor, M., and Miller, H. L., Cambridge University Press, Cambridge, UK and New York, NY, USA, 996 pp., 2007.

Jenkinson, D. S., Adams, D. E., and Wild, A.: Model estimates of $\mathrm{CO}_{2}$ emissions from soil in response to global warming, Nature, 351, 304-306, 1991.

Jones, S. K., Rees, R. M., Kosmas, D., Ball, B. C., and Skiba, U. M.: Carbon sequestration in a temperate grassland: management and climatic controls, Soil Use and Manage., 22, 132-142, 2006.

Kätterer, T., Reichstein, M., Andrén, O., Lomander, A., and Andrén, O.: Temperature dependence of organic matter decomposition: a critical review using literature data analyzed with different models, Biol Fertil Soils, 27, 258-262, 1998.

Kesik, M., Ambus, P., Baritz, R., Brüggemann, N., ButterbachBahl, K., Damm, M., Duyzer, J., Horváth, L., Kiese, R., Kitzler, B., Leip, A., Li, C., Pihlatie, M., Pilegaard, K., Seufert, S., Simpson, D., Skiba, U., Smiatek, G., Vesala, T., and ZechmeisterBoltenstern, S.: Inventories of $\mathrm{N}_{2} \mathrm{O}$ and $\mathrm{NO}$ emissions from European forest soils, Biogeosciences, 2, 353-375, doi:10.5194/bg2-353-2005, 2005.

Krift, T. A. J. van der and Berendse, F.: Root life spans of four grass species from habitats differing in nutrient availability, Funct. Ecol., 16, 198-203, 2002.

Kulshreshtha, S. and Sobool, D.: Comparative Greenhouse Gas Emission Intensities from Irrigated and Dryland Agricultural Activities in Canada, Canadian Water Res. J., 31, 157-172, 2006.

Lal, R.: Carbon management in agricultural soils, Mitig. Adapt. Strat. Global Change, 12, 303-322, 2006.

Lazzarotto, P., Calanca, P., Semenov, M., and Fuhrer, J.: Transient responses to increasing $\mathrm{CO}_{2}$ and climate change in an unfertilized grass-clover sward, Climate Res., 41, 221-232, 2010.

Leifeld, J. and Fuhrer, J.: Organic farming and soil carbon sequestration: What do we really know about the benefits? AMBIO, 39 , 585-599, 2010.

Leifeld, J., Bassin, S., and Fuhrer, J.: Carbon stocks in Swiss agricultural soils predicted by land-use, soil characteristics, and altitude, Agric. Ecosyst. Environ., 105, 255-266, 2005.

Leifeld, J., Ammann, C., Neftel, A., and Fuhrer, J.: A comparison of repeated soil inventory and carbon flux budget to detect soil carbon stock changes after conversion from cropland to grasslands, Glob. Change Biol., 17, 3366-3375, 2011.

Li, C., Frolking, S., and Frolking, T. A.: A model of nitrous oxide evolution from soil driven by rainfall events: 1 . Model structure and sensitivity, J. Geophys. Res., 97, 9759-9776, 1992.

Louault, F., Pillar, V. D., Aufrère, J., Garnier, E., and Soussana, J.: Plant traits and functional types in response to reduced disturbance in a semi-natural grassland, J. Veg. Sci., 16, 151-160, 2005.

Merta, M., Seidler, C., and Fjodorowa, T.: Estimation of evaporation components in agricultural crops, Biom. and Life Sc., 61, 280 283, 2006.

Müller, C.: Modelling Soil-Biosphere Interactions, CAB International, 2000.

Parton, W. J., Schimel, D. S., Cole, C. V., and Ojima, D. S.: Analysis of factors controlling soil organic matter levels in Great Plains grasslands, Soil Sci. Soc. Am. J., 51, 1173-1179, 1987. 
Poeplau, C., Don, A., Vesterdal, L., Leifeld, J., Wesemael, B. van, Schumacher, J., and Gensior, A.: Temporal dynamics of soil organic carbon after land-use change in the temperate zone - carbon response functions as a model approach, Glob. Change Biol., 17, 2415-2427, 2011.

Priestley, C. H. B. and Taylor, R. J.: On the assessment of surface heat flux and evaporation using large-scale parameters, Mon. Weather Rev., 100, 81-82, 1972.

Riedo, M., Grub, A., Rosset, M., and Fuhrer, J.: A pasture simulation model for dry matter production, and fluxes of carbon, nitrogen, water and energy, Ecol. Model., 105, 141-183, 1998.

Riedo, M., Gyalistras, D., and Fuhrer, J.: Net primary production and carbon stocks in differently managed grasslands: simulation of site-specific sensitivity to an increase in atmospheric $\mathrm{CO}_{2}$ and to climate change, Ecol. Model., 134, 207-227, 2000.

Ryle, G. J. A., Weledge, J., Tewson, V., and Powell, C. E.: Influence of Elevated $\mathrm{CO}_{2}$ and Temperature on the Photosynthesis and Respiration of White Clover Dependent on $\mathrm{N}_{2} 2$ Fixation, Ann. Bot., 70, 213-220, 1992.

Saugier, B. and Katerji, N.: Some plant factors controlling evapotranspiration, Agricultural and Forest Meteorology, Agr. Forest Meteorol., 54, 263-277, 1991.

Schimel, D. S.: Terrestrial ecosystems and the carbon cycle, Glob. Change Biol., 1, 77-91, 1995.

Semenov, M. A.: Development of high resolution UKCIP02-based climate change scenarios in the UK, Agric. For. Meteorol., 144, 127-138, 2007.
Steduto, P., Hsiao, T. C., Raes, D., and Fereres, E.: AquaCrop-The FAO crop model to simulate yield response to water: I Concepts and underlying principles, Agron. J., 101, 426-437, 2009.

Thornley, J. H. M. and Johnson, I. R.: Plant and Crop Modeling, Clarendon Press Oxford, 1990.

Van Wesemael, B., Paustian, K., Meersmans, J., Goidts, E., and Barancikove, G.: Agricultural management explains historic changes in regional soil carbon stocks, Proc. Natl. Acad. Sci. USA, 107, 14926-14930, 2010.

Vidale, P. L., Lüthi, D., Frei, C., Seneviratne, S., and Schär, C.: Predictability and uncertainty in a regional climate model, J. Geophys. Res., 108, 4586, 2003.

Wand, S. J. E., Midgley, G. F., Jones, M. H., and Curtis, P. S.: Responses of wild $\mathrm{C} 4$ and $\mathrm{C} 3$ grass (Poaceae) species to elevated atmospheric $\mathrm{CO}_{2}$ concentration: a meta-analytic test of current theories and perceptions, Glob. Change Biol., 5, 723-741, 1999.

$\mathrm{Xu}, \mathrm{X}$., Liu, W., and Kiely, G.: Modeling the change in soil organic carbon (SOC) of grassland in response to climate change: effects of measured versus modeled carbon pools for initializing RothC model, Agric. Ecosyst. Environ., 140, 372-381, 2011.

Zeeman, J. M.: Environmental processes affecting the carbon dioxide budget of grasslands along an elevational gradient in Switzerland, Doctoral Thesis, ETH Zurich, http://e-collection.ethbib. ethz.ch/view/eth:41494, 2008. 